\title{
Carbon Mineralogy and Crystal Chemistry
}

\author{
Robert M. Hazen \\ Geophysical Laboratory, Carnegie Institution of Washington \\ 5251 Broad Branch Road NW \\ Washington, DC 20015, U.S.A. \\ rhazen@ciw.edu
}

Robert T. Downs

Department of Geosciences, University of Arizona

1040 East $4^{\text {th }}$ Street

Tucson, Arizona 85721-0077, U.S.A.

rdowns@u.arizona.edu

Adrian P. Jones

Earth Sciences, University College London

Gower Street

London WC1E 6BT, United Kingdom

adrian.jones@ucl.ac.uk

Linda Kah

Department of Earth \& Planetary Sciences

University of Tennessee

Knoxville, Tennessee 37996-4503, U.S.A.

lckah@utk.edu

\section{INTRODUCTION}

Carbon, element 6, displays remarkable chemical flexibility and thus is unique in the diversity of its mineralogical roles. Carbon has the ability to bond to itself and to more than 80 other elements in a variety of bonding topologies, most commonly in 2-, 3-, and 4-coordination. With oxidation numbers ranging from -4 to +4 , carbon is observed to behave as a cation, as an anion, and as a neutral species in phases with an astonishing range of crystal structures, chemical bonding, and physical and chemical properties. This versatile element concentrates in dozens of different Earth repositories, from the atmosphere and oceans to the crust, mantle, and core, including solids, liquids, and gases as both a major and trace element (Holland 1984; Berner 2004; Hazen et al. 2012). Therefore, any comprehensive survey of carbon in Earth must consider the broad range of carbon-bearing phases.

The objective of this chapter is to review the mineralogy and crystal chemistry of carbon, with a focus primarily on phases in which carbon is an essential element: most notably the polymorphs of carbon, the carbides, and the carbonates. The possible role of trace carbon in nominally acarbonaceous silicates and oxides, though potentially a large and undocumented reservoir of the mantle and core (Wood 1993; Jana and Walker 1997; Freund et al. 2001; McDonough 2003; Keppler et al. 2003; Shcheka et al. 2006; Dasgupta 2013; Ni and Keppler 2013; Wood et al. 2013), is not considered here. Non-mineralogical carbon-bearing phases 
treated elsewhere, including in this volume, include C-O-H-N aqueous fluids (Javoy 1997; Zhang and Duan 2009; Jones et al. 2013; Manning et al. 2013); silicate melts (Dasgupta et al. 2007; Dasgupta 2013; Manning et al. 2013); carbonate melts (Cox 1980; Kramers et al. 1981; Wilson and Head 2007; Walter et al. 2008; Jones et al. 2013); a rich variety of organic molecules, including methane and higher hydrocarbons (McCollom and Simoneit 1999; Kenney et al. 2001; Kutcherov et al. 2002; Sherwood-Lollar et al. 2002; Scott et al. 2004; Helgeson et al. 2009; McCollom 2013; Sephton and Hazen 2013); and subsurface microbial life (Parkes et al. 1993; Gold 1999; Chapelle et al. 2002; D'Hondt et al. 2004; Roussel et al. 2008; Colwell and D'Hondt 2013; Schrenk et al. 2013; Meersman et al. 2013; Anderson et al. 2013).

The International Mineralogical Association (IMA) recognizes more than 380 carbonbearing minerals (http://rruff.info/ima), including carbon polymorphs, carbides, carbonates, and a variety of minerals that incorporate organic carbon in the form of molecular crystals, organic anions, or clathrates. This chapter reviews systematically carbon mineralogy and crystal chemistry, with a focus on those phases most likely to play a role in the crust. Additional high-temperature and high-pressure carbon-bearing minerals that may play a role in the mantle and core are considered in the next chapter on deep carbon mineralogy (Oganov et al. 2013).

\section{SYSTEMATIC CARBON MINERALOGY}

Carbon, a non-metal that typically forms covalent bonds with a variety of other elements, is the most chemically adaptable element of the periodic table. In an ionic sense, element 6 can act as a cation with oxidation number +4 , as in carbon dioxide $\left(\mathrm{CO}_{2}\right)$ or in the carbonate anion $\left(\mathrm{CO}_{3}{ }^{-2}\right)$. Alternatively, carbon can act as an anion with oxidation number as low as -4 , as in methane $\left(\mathrm{CH}_{4}\right)$ and in other alkanes. Carbon also frequently displays a range of intermediate oxidation number states from +2 in carbon monoxide $(\mathrm{CO})$ or -2 in methanol $\left(\mathrm{CH}_{3} \mathrm{OH}\right)$, as well as occurring in its neutral state $(\mathrm{C})$ in a variety of carbon allotropes.

Carbon chemistry is also enriched by the ability of $\mathrm{C}$ to form single, double, or triple bonds, both with itself and with a wide range of other chemical elements. In many carbon compounds each $\mathrm{C}$ atom bonds to 4 other atoms by single bonds, as in methane and carbon tetrafluoride $\left(\mathrm{CF}_{4}\right)$. But carbon commonly forms double bonds with itself, for example in ethene $\left(\mathrm{H}_{2} \mathrm{C}=\mathrm{CH}_{2}\right)$, oxygen in carbon dioxide $(\mathrm{O}=\mathrm{C}=\mathrm{O})$, or sulfur in carbon disulfide $(\mathrm{S}=\mathrm{C}=\mathrm{S})$, and it can form triple bonds with itself, as in ethylene (commonly known as acetylene; $\mathrm{HC} \equiv \mathrm{CH}$ ), or with nitrogen, as in hydrogen cyanide $(\mathrm{HC} \equiv \mathrm{N})$. Carbon's remarkably diverse mineralogy arises in part from this unmatched range of valence states and bond types.

In the following sections we review the systematic mineralogy of carbon, including carbon allotropes, carbides, carbonates, and minerals that incorporate organic carbon molecules.

\section{Carbon allotropes}

The element carbon occurs in several allotropes, including graphite, diamond, lonsdaleite, fullerenes (including buckyballs and carbon nanotubes), graphene, and several non-crystalline forms (Table 1). These varied carbon allotropes exhibit extremes in physical and chemical properties-variations that reflect differences in their atomic structures. Diamond and lonsdaleite are the hardest known substances, whereas graphite is among the softest. Transparent diamond is an exceptional electrical insulator while possessing the highest known thermal conductivity at room temperature, whereas opaque graphite is an electrical conductor and thermal insulator. Isotropic diamond is widely used as a tough abrasive, whereas anisotropic graphite is employed as a lubricant. Diamond possesses the highest nuclear density of any known condensed phase at ambient conditions (Zhu et al. 2011) and is predicted to have highpressure phases of even greater density (Oganov et al. 2013), whereas some carbon nanogels feature among the lowest known nuclear densities. 
Here we focus on the essential characteristics of the three most common minerals of native carbon — graphite, diamond, and lonsdaleite-all of which play roles in Earth's subsurface carbon cycle. For more comprehensive reviews of the chemical and physical properties of these carbon polymorphs see Bragg et al. (1965), Deer et al. (1966), Field (1979), Davies (1984), Klein and Hurlbut (1993), Harlow (1998), and Zaitsev (2001).

Graphite. Carbon forms covalent bonds with itself in all of the carbon polymorphs, in which $\mathrm{C}$ adopts one of two coordination environments (Table 1). In graphite, graphene, buckyballs, nanotubes, and several types of amorphous and glassy carbon, the carbon atoms are in planar three-coordination. This trigonal coordination, with typical C-C distances of $\sim 1.42 \mathrm{~A}$ and $\mathrm{C}-\mathrm{C}-\mathrm{C}$ angles close to $120^{\circ}$, results from the hybridization of carbon's electrons into three orbitals, known as the $s p^{2}$ bonding configuration because the $2 s$ orbital mixes (or hybridizes) with two $2 p$ orbitals to form three $s p^{2}$ orbitals.

The hexagonal layered structure of graphite (Fig. 1a; Animation 1) features electrically neutral, monoatomic, flat carbon layers, which bond to each other through van der Waals attractions and which are separated from each other by $3.41 \AA$ A. This layered structure leads to the distinctive, highly anisotropic properties of graphite (Fig. 1b). Individual carbon layers, which are known as graphene when meticulously separated from a graphite crystal or vapor deposited, are extremely strong and display unique electronic and mechanical properties (Geim and Novoselov 2007; Geim 2009). Weak van der Waal's forces between these layers lead to graphite's applications in lubricants and as pencil "lead."

Natural graphite is a common crustal mineral that occurs most abundantly in metamorphic rocks in pods and veins as a consequence of the reduction and dehydration of sediments rich in carbon (e.g., Klein and Hurlbut 1993). Commercial metamorphic graphite deposits, notably from China, India, and Brazil, are exploited in the manufacture of pencils, lubricants, steel, and brake linings. Graphite is also found as an accessory mineral in some igneous rocks and as a micro- or nano-phase in a variety of meteorites. In these diverse lithologies graphite is commonly precipitated in veins from reduced C-O-H fluids (Rumble and Hoering 1986; Rumble et al. 1986). In addition, graphite can crystallize from the vapor state in the carbon-rich, expanding hot envelopes of energetic late-stage stars, including supernovas.
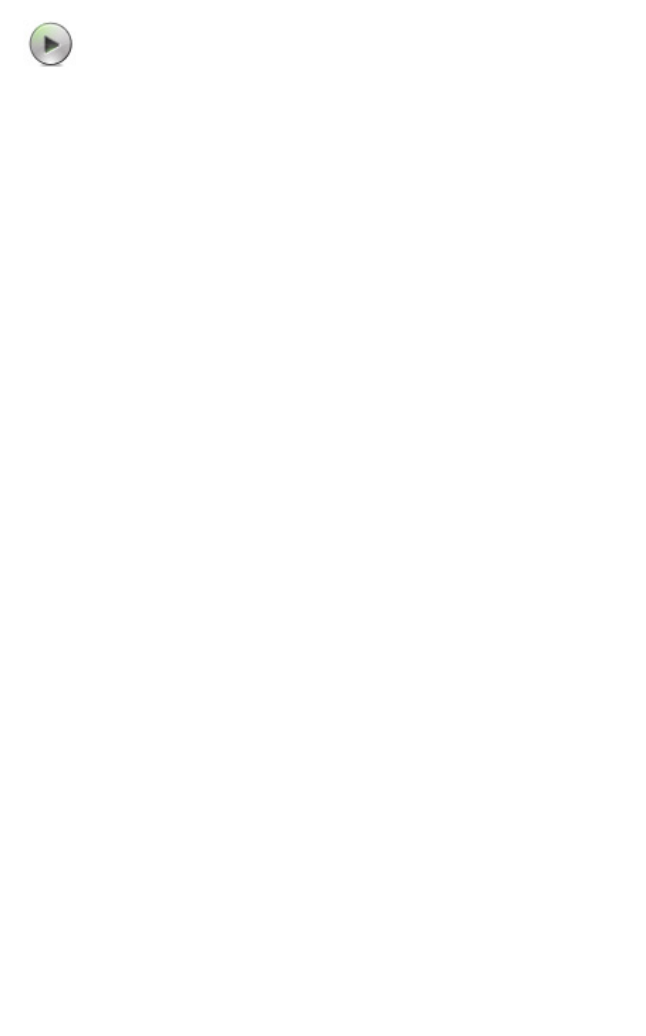

Figure 1. Graphite. (a) The graphite (native C) crystal structure (hexagonal, space group $P 6_{3} / \mathrm{mmc} ; a=$ layers of 3-coordinated carbon, linked by van der Waals interactions. (b) Natural graphite crystals reflect crystal displays basal pinacoid and prism faces. The crystal, associated with calcite, is from the Crestmore John A. Jaszczak. [Animation 1: For readers of the electronic version, click the image for an animation of the graphite crystal structure.] $2.464 \AA ; c=6.736 \AA ; Z=4)$ incorporates monoatomic the hexagonal crystal structure. This $1 \mathrm{~mm}$ diamete quarries, Riverside Co., California. Photo courtesy of
Diamond and lonsdaleite. In contrast to the $s p^{2}$ bonding environment of carbon in graphite, each carbon atom can bind to 4 adjacent $\mathrm{C}$ atoms in tetrahedral coordination, as exemplified by the diamond and lonsdaleite polymorphs (Figs. 2 and 3; Animations 2 and 3). The $\mathrm{C}-\mathrm{C}$ distance in these minerals are $\sim 1.54 \AA$, while $\mathrm{C}-\mathrm{C}-\mathrm{C}$ angles are close to the ideal tetrahedral value of $109.5^{\circ}$. This tetrahedral bonding configuration reflects the hybridization of one $2 s$ and three $2 p$ orbitals from each carbon atom to form four $s p^{3}$ orbitals.

The structures of cubic diamond and hexagonal lonsdaleite are similar: both forms of carbon feature tetrahedral coordination of $\mathrm{C}$ in a three-dimensional framework. However, given a flat layer of linked carbon tetrahedra with all vertices pointed in the same direction (layer A), there exist two ways to stack subsequent layers, in orientations described as B or C. The diamond structure represents a three-layer stacking sequence of $[\ldots \mathrm{ABCABC} \ldots]$ along the (111) cubic direction, whereas lonsdaleite stacking is two-layer $[\ldots \mathrm{ABAB} \ldots]$ along the (001) hexagonal direction. A similar stacking difference distinguishes the cubic and hexagonal forms of a number of topologically similar mineral pairs, such as the polymorphs of zinc sulfide $(\mathrm{ZnS})$, sphalerite and wurtzite, respectively. Note also that the stacking sequence of these carbon polymorphs can incorporate errors, as is often the case with lonsdaleite that has formed by impact shock of graphite (Frondel and Marvin 1967).
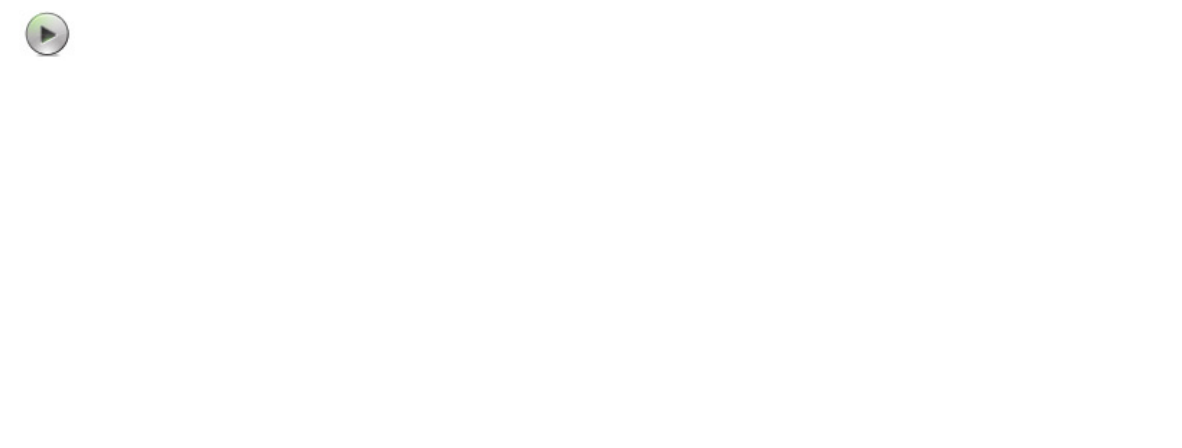

Figure 2. (a) The diamond (native C) crystal structure (cubic, space group $F d 3 m ; a=3.560 \AA ; Z=8$ ) features a framework of tetrahedrally coordinated carbon atoms. (b) A natural diamond crystal reflects the cubic crystal structure. The semi-translucent diamond cube (ref. no. S014632) is $24.3 \times 21.8 \times 21.7 \mathrm{~mm}$ in size and weighs 156.381 carats $(31.3 \mathrm{gm})$ and is shown with a 1-carat diamond for scale. It is represented to be from Ghana Photo courtesy of Harold and Erica Van Pelt. [Animation 2: For readers of the electronic version, click the image for an animation of the diamond crystal structure.]

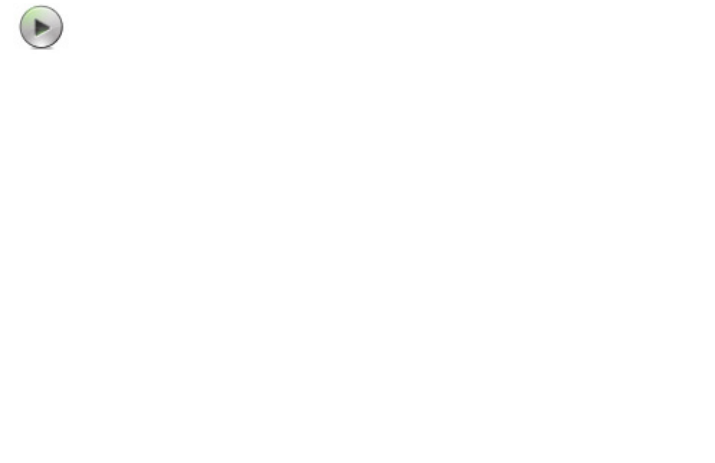

Figure 3. The lonsdaleite (native C) crystal structure (hexagonal, space group $P 6_{3} / m m c ; a=2.52 \AA ; c=$ $4.12 \AA ; Z=4)$. [Animation 3: For readers of the electronic version, the lonsdaleite crystal structure.]. 
The framework structures of diamond and lonsdaleite lead to their superlative physical and chemical properties (Davies 1984). Notably, the exceptional hardness and strength of these phases arises from the strong three-dimensional network of $\mathrm{C}-\mathrm{C}$ bonds. Recent theoretical studies on diamond and lonsdaleite suggest that diamond possesses the greater strength (Pan et al. 2009; Lyakhov and Oganov 2011).

The key to understanding the contrasting properties of the natural carbon allotropes is their different pressure-temperature stability fields. The deep origin of diamond was first recognized in the years following the widely publicized discovery of the 20-carat Eureka diamond by children playing in a dry central South African streambed in 1866, and the even more dramatic 83.5-carat Star of South Africa diamond two years later. A subsequent diamond rush brought more than 10,000 prospectors to the semi-desert region, and inevitably led to the recognition of diamond in their volcanic host rock, dubbed kimberlite (Davies 1984; Hazen 1999). The South African kimberlites' cone-shaped deposits, which cut vertically through shattered country rock, spoke of violent explosive eruptions from great depth (Lewis 1887; Bergman 1987; Mitchell 1995).

The hypothesis that diamond comes from depth was reinforced by determination of the crystal structures of diamond versus graphite (Bragg and Bragg 1913; Hull 1917; Hassel and Mark 1924; Bernal 1924). The higher coordination number of carbon in diamond (4-fold) compared to graphite (3-fold), coupled with its much greater density ( $\left.3.51 \mathrm{vs} .2 .23 \mathrm{~g} / \mathrm{cm}^{3}\right)$, provided physical proof that diamond was the higher-pressure polymorph. Early determinations of the carbon phase diagram (Rossini and Jessup 1938), though refined in subsequent years (Bundy et al. 1961; Kennedy and Kennedy 1976; Day 2012; Fig. 4), revealed that diamond is the higher-pressure, lower-temperature form and that, under a normal continental geotherm, diamond likely forms at depths greater than 100 kilometers. By contrast, the steeper geothermal gradients of the oceanic crust and mantle preclude diamond formation, at least within the suboceanic upper mantle and transition zone.

Efforts to synthesize diamond under extreme laboratory conditions extend back to the early 1800s, long before the crucial role of high-pressure was recognized (Mellor 1924;

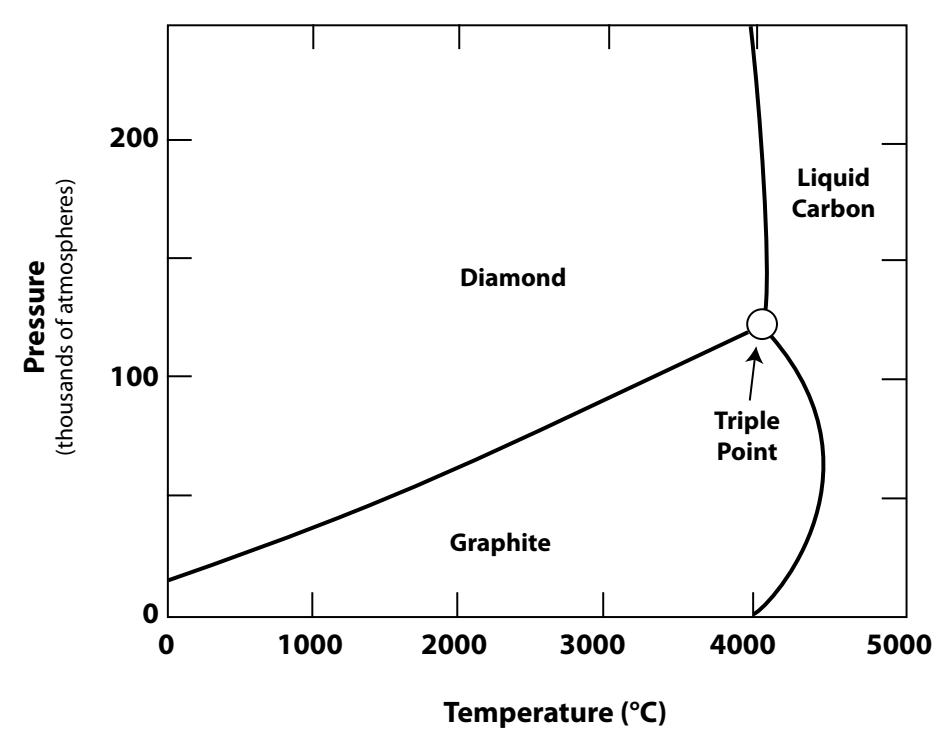

Figure 4. The carbon phase diagram (after Hazen 1999).
Hazen 1999). Among the most renowned $19^{\text {th }}$-century chemists to try his hand at diamond making was Frederick-Henri Moissan, who won the Nobel Prize for his risky isolation of the dangerous element fluorine. Moissan employed a novel electric arc furnace to generate record temperatures $\sim 3000{ }^{\circ} \mathrm{C}$. Moissan initially thought he was successful in synthesizing diamond but is now known to have formed hard, transparent crystals of silicon carbide-a compound that he also discovered in nature, and what is now known as the mineral moissanite (Moissan 1904a; Hazen 1999; see below). Numerous other heroic efforts prior to 1950 also failed (Bridgman 1931, 1946; von Platen 1962; Coes 1962). In spite of the relatively accessible pressure-temperature regime of diamond stability $>4$ GPa (approximately 40,000 atm or $40 \mathrm{kbar}$ ), the transition from graphite to diamond is kinetically inhibited. The keys to facile diamond synthesis-employing a liquid metal flux coupled with sustained pressures above $5 \mathrm{GPa}$ and temperatures above $1200{ }^{\circ} \mathrm{C}$-were not achieved until the post-World War II efforts by scientists at the General Electric Research Laboratory in Schenectady, New York (Bundy et al. 1955; Suits 1960, 1965; Wentorf 1962; Hall 1970; Strong 1989; Hazen 1999). The breakthrough of high-pressure diamond synthesis by Francis Bundy, Tracy Hall, Herbert Strong, and Robert Wentorf in December of 1954 led to what is today a multi-billion dollar industry that supplies annually hundreds of tons of industrial diamond abrasives.

Two other synthesis techniques have expanded the varieties of diamond available for commercial exploitation. Of special interest are efforts to generate diamond and lonsdaleite under shock conditions that mimic bolide impact events (DeCarli and Jamieson 1961; Beard 1988). In some meteorites lonsdaleite and/or diamond is found to replace graphite in crystallites that retain a hexagonal shape (Langenhorst et al. 1999; El Goresy et al. 2001; Langenhorst and Deutsch 2012). In this rapid, solid-state martensitic transition the flat, graphitic $s p^{2}$ planes of carbon atoms shift relative to each other and buckle to produce a $s p^{3}$ array of $\mathrm{C}$ layers that are rather disordered in their stacking arrangement.

The subsequent discovery of techniques for diamond and lonsdaleite synthesis by vapor deposition at low-pressure conditions that mimic diamond formation in expanding stellar envelopes has greatly increased the potential for diamond use in science and industry (Angus et al. 1968; Derjaguin and Fedoseev 1968; Angus and Hayman 1988; Spear and Dismukes 1994; Irifune and Hemley 2012). These varied efforts in diamond synthesis have produced exceptional new materials, including isotopically pure diamonds with the highest recorded thermal conductivity, semiconducting diamonds, nano-crystalline polishing powders, lonsdaleite crystals that are harder than many natural diamond, and a range of deeply colored flawless synthetic gemstones up to 10 carats (Liang et al. 2009; Meng et al. 2012).

Intense research on natural diamond is also providing important insights regarding Earth's geochemical and tectonic evolution. A number of recent studies focus on diamond's rich and revealing suites of oxide, silicate, carbide, and sulfide inclusions from depths of up to perhaps 850 kilometers - mantle samples that provide evidence for aspects of geochemical and tectonic evolution over more than 3 billion years of Earth history (Shirey et al. 2002; McCammon et al. 2004; Sommer et al. 2007; Pearson et al. 2007; Gübelin and Koivula 2008; Shirey and Richardson 2011; Walter et al. 2011; Shirey et al. 2013).

\section{Carbides}

Carbides, which form when carbon bonds to a less electronegative element, are represented by dozens of synthetic compounds that have a range of industrial applications (Ettmayer and Lengauer 1994). The International Mineralogical Association has recognized 10 different naturally occurring carbide minerals (Tables 2 and 3; http://rruff.info/ima/). Although rare and volumetrically trivial as reservoirs of carbon in the crust, they may represent a significant volume of carbon in Earth's deep interior, and thus may provide insight to the deep carbon cycle (Dasgupta 2013; Wood et al. 2013). 
Table 2. Natural carbide minerals (data compiled from http://MinDat.Org locality and species databases).

\begin{tabular}{llll}
\hline Mineral $(\mathrm{Key})$ & Formula & Paragenesis* & Locality register** \\
\hline Cohenite $(\mathrm{C})$ & $(\mathrm{Fe}, \mathrm{Ni}, \mathrm{Co})_{3} \mathrm{C}$ & $1,2,4$ & $\mathrm{G} 1, \mathrm{G} 2, \mathrm{M} 1, \mathrm{R} 1, \mathrm{R} 2$ \\
Haxonite $(\mathrm{H})$ & $(\mathrm{Fe}, \mathrm{Ni})_{23} \mathrm{C}_{6}$ & 2 & $\mathrm{M} 1$ \\
Isovite $(\mathrm{I})$ & $(\mathrm{Cr}, \mathrm{Fe})_{23} \mathrm{C}_{6}$ & 4 & $\mathrm{R} 3, \mathrm{R} 4$ \\
Khamrabaevite $(\mathrm{K})$ & $(\mathrm{Ti}, \mathrm{V}, \mathrm{Fe}) \mathrm{C}$ & $2,4 ?$ & $\mathrm{M} 1, \mathrm{~T} 1, \mathrm{U} 1, \mathrm{U} 2$ \\
Moissanite $(\mathrm{M})$ & $\mathrm{SiC}$ & $2,3,4$ & $\mathrm{C} 1-\mathrm{C} 6, \mathrm{M} 1, \mathrm{R} 5, \mathrm{R} 6, \mathrm{~S} 1, \mathrm{~T} 2, \mathrm{U} 2$ \\
Niobocarbide $(\mathrm{N})$ & $(\mathrm{Nb}, \mathrm{Ta}) \mathrm{C}$ & 4 & $\mathrm{R} 7$ \\
Qusongite $(\mathrm{Q})$ & $\mathrm{WC}$ & $1,3,4$ & $\mathrm{C} 3, \mathrm{C} 4, \mathrm{C} 7$ \\
Tantalcarbide $(\mathrm{Ta})$ & $(\mathrm{Ta}, \mathrm{Nb}) \mathrm{C}$ & 4 & $\mathrm{R} 7$ \\
Tongbaite $(\mathrm{To})$ & $\mathrm{Cr}_{3} \mathrm{C}_{2}$ & 4 & $\mathrm{C} 8, \mathrm{R} 3$ \\
Yarlongite $(\mathrm{Y})$ & $\left(\mathrm{Cr} \mathrm{Fe}_{4} \mathrm{Fe}_{4} \mathrm{Ni}\right) \mathrm{C}_{4}$ & 4 & $\mathrm{C} 4$ \\
\hline
\end{tabular}

* 1 = coll fire or intrusion in coal/graphite; 2 = meteorite; 3 = kimberlite; 4 = other ultramafic

**See Table 3 for locality key

All metal carbides are refractory minerals; they have relatively high solidus and liquidus temperatures, with melting points typically above $2400{ }^{\circ} \mathrm{C}$ (Nadler and Kempter 1960; Lattimer and Grossman 1978). A number of these minerals are found in association with diamond and other high-pressure phases, as well as with assemblages of unusual reduced minerals, including native $\mathrm{Al}, \mathrm{Fe}, \mathrm{Si}, \mathrm{Sn}, \mathrm{W}$, and more than a dozen other native metallic elements, as well as exotic sulfides, phosphides, and silicides (Table 4). Carbides, along with diamond, may thus represent Earth's deepest surviving minerals, and may prove a relatively unexplored window on the nature of the deep mantle environment and the deep carbon cycle.

Moissanite. Moissanite ( $\alpha$-SiC), also known commercially as carborundum when sold as an abrasive (hardness 9.5), is the most common of the natural carbides. Produced synthetically for more than a century (Acheson 1893), moissanite is used in numerous applications, including automobile parts (e.g., brakes and clutches), bulletproof vests, light-emitting diodes, semiconductor components, anvils for high-pressure research and, since 1998, it has been marketed as inexpensive diamond-like artificial gemstones (Bhatnagar and Baliga 1993; Xu and Mao 2000; Madar 2004; Saddow and Agarwal 2004).

Since its discovery in 1893 by Henri Moissan in mineral residues from the Canyon Diablo meteor crater in Arizona (Moissan 1904b), natural moissanite has been found in dozens of localities, including meteorites, serpentinites, chromitites, ophiolite complexes, and in close association with diamond in kimberlites and eclogites (Lyakhovich 1980; Leung et al. 1990; Alexander 1990, 1993; Di Pierro et al. 2003; Lee et al. 2006; Qi et al. 2007; Xu et al. 2008; Trumbull et al. 2009; Shiryaev et al 2011; see also http://MinDat.org). While some occurrences of moissanite are apparently of near-surface origin, including sites of forest fires and contact metamorphism of silicate magmas with coal beds (Sameshima and Rodgers 1990), silicon carbide also represents one of the deepest mantle minerals known to reach the surface. The discovery of moissanite inclusions in diamond (Moore and Gurney 1989; Otter and Gurney 1989; Leung 1990; Gorshkov et al. 1997), combined with observations of native silicon and Fe-Si alloy inclusions in moissanite (Trumbull et al. 2009), may point to an origin in reduced mantle microenvironments. However, further research is required to determine the range of oxygen fugacities under which moissanite is stable at mantle pressures and temperatures.

Occurrences of silicon carbide in mantle-derived kimberlites and several ophiolite complexes reflect its stability at high pressure and very low oxygen fugacity (Mathez et al. 1995). Secondary ion mass spectrometric (SIMS) analysis shows that ophiolite-hosted
Table 3. Natural carbide locality register, with associated reduced and/or high- $P$ mineral species (data compiled from http://MinDat.Org locality and species databases). Several moissanite localities of poorly-defined paragenesis are not included.

\begin{tabular}{|c|c|c|c|c|}
\hline Code & Locality & Carbides* & Type** & Associated Phases*** \\
\hline \multicolumn{5}{|c|}{ Canada } \\
\hline $\mathrm{C} 1$ & Jeffrey Mine, Quebec & M & Ser & Gra, Cu, Awa, IMA, Hea, Pyr, Sha \\
\hline \multicolumn{5}{|l|}{ China } \\
\hline $\mathrm{C} 2$ & Fuxian kimberlite field, Liaoning Prov. & M & Kim & Dia, Gra, Lon, Fe \\
\hline $\mathrm{C} 3$ & $\begin{array}{l}\text { Mengyin kimberlite field, Linyi } \\
\text { Prefecture }\end{array}$ & M, Q & Kim & Dia, Cr, Fe, Pb, W, Pen, Pol, Coe \\
\hline $\mathrm{C} 4$ & Luobusa ophiolite, Tibet & $\mathrm{M}, \mathrm{Q}, \mathrm{Y}$ & Oph & $\begin{array}{l}\text { Dia, } \mathrm{Gra}, \mathrm{Al}, \mathrm{Cr}, \mathrm{Cu}, \mathrm{In}, \mathrm{Fe}, \mathrm{Ni} \\
\text { Os, Pd, Rh, Ru, Si, Ag, Sn, Ti, W, } \\
\text { Zn, Zan, Ala, Wus, Luo }\end{array}$ \\
\hline $\mathrm{C} 5$ & Picrite lava outcrop, Yunnan Prov. & M & Ser & $\mathrm{Cu}, \mathrm{Zn}$ \\
\hline C6 & Dongjiashan Hill, Dabie Mountains & M & Ser & $\mathrm{Dia}, \mathrm{Si}$ \\
\hline $\mathrm{C} 7$ & $\begin{array}{l}\text { Yangliuping N-Cu-PGE Deposit, Sichuan } \\
\text { Prov. }\end{array}$ & $\mathrm{Q}$ & UGr & $\mathrm{Cr}$, Pt, Dan, Cub, Lau, Lin, Vio \\
\hline $\mathrm{C} 8$ & Liu Village, Henan Prov. & To & Ult & $\begin{array}{l}\mathrm{Cr}, \mathrm{Cu}, \mathrm{Fe}, \mathrm{Pb}, \mathrm{Alt}, \mathrm{Awa}, \mathrm{Bi} 2, \mathrm{Cub} \text {, } \\
\text { Pen, Pyr, Vio, }\end{array}$ \\
\hline
\end{tabular}

Germany

G1 Bühl, Weimar, Kassel, Hesse $\quad$ C $\quad$ MCo $\quad F$

Greenland
G2 Disko Island, Kitaa Prov.
C
Ult $\quad \mathrm{Gra}, \mathrm{Fe}, \mathrm{Pb}, \mathrm{Arm}$, Sha, Tro, Sch

Meteorites

M1 Various localities

$\mathrm{C}, \mathrm{H}, \mathrm{K}, \mathrm{M}$

Russia

R1 Khungtukun Massif, Khatanga, Siberia C

R2 Coal Mine 45, Kopeisk, Urals C

R3 Is River, Isovsky District, Urals I, To

R4 Verkhneivinsk, Neiva River, Urals

R5 Billeekh intrusion, Saha Rep., Siberia

R6 Avacha volcano, Kamchatka M

R7 Avorinskii Placer, Baranchinsky Massif, N, Ta Urals

South Africa

S1 Monastery Mine, Free State Prov. $\quad$ M $\quad$ Kim Dia, Maj

Tajikistan

T1 Chinorsai intrusion, Viloyati Sogd $\quad \mathrm{K} \quad \mathrm{Gra}, \mathrm{Bi}, \mathrm{Fe}, \mathrm{Bis}$

Uzbekistan

U1 Ir-Tash Stream Basin, Tashkent Viloyati K ??? Gra, Gue, Sue

U2 Koshmansay River, Tashkent Viloyati $\quad$ K, M $\quad$ Lam Ala, Mav

*See Table 2 for key to carbides

** $\mathrm{CoF}=$ coal fire; $\mathrm{GCo}$ = gabbro intrusion in coal; $\mathrm{Gra}=$ granodiorite; $\mathrm{Kim}=$ kimberlite; $\mathrm{Lam}=$ lamproite; $\mathrm{Oph}=$ ophiolite;

$\mathrm{Pic}=$ picrite; Pla = placer; Ser $=$ serpentinite; UGr $=$ ultramafic intrusion in graphite schist; Ult = unspecified ultramafic

***:See Table 4 for key to associated phases 


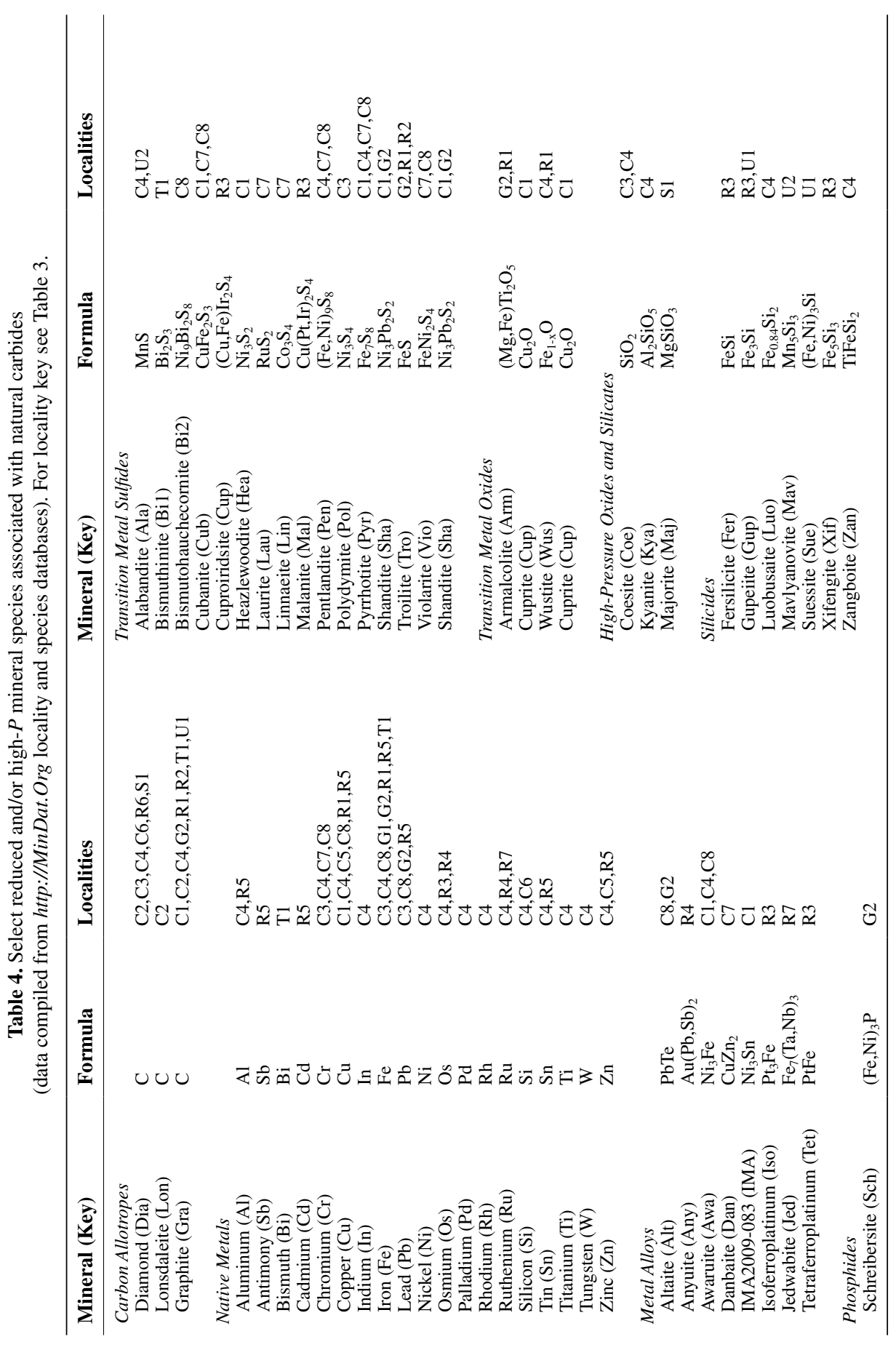

moissanite has a distinctive ${ }^{13} \mathrm{C}$-depleted isotopic composition $\left(\delta^{13} \mathrm{C}\right.$ from -18 to $-35 \%$, $n=36)$, which is significantly lighter than the main carbon reservoir in the upper mantle $\left(\delta^{13} \mathrm{C}\right.$ near $-5 \%$ o). Alternatively, significant isotope fractionation between carbide and diamond has been observed in high-pressure experiments ( -7 per mil at 5 GPa; Mikhail et al. 2010; Mikhail 2011), greatly complicating the potential for identification of carbon reservoirs through carbon isotope systematics of mantle-derived samples (Mikhail et al. 2011). It has been suggested that moissanite may also occur in the lower mantle, where the existence of ${ }^{13} \mathrm{C}$-depleted carbon is strongly supported by studies of extraterrestrial carbon (Trumbull et al. 2009).

Moissanite, like diamond, also forms by vapor deposition (Hough et al. 1997) and it is relatively common in space in the envelopes of carbon-rich AGB stars. It is subsequently carried as a pre-solar guest in carbonaceous chondrites. The origins of moissanite and other carbides have been inferred from unusual variations in both C-isotopes and N-isotopes (Daulton et al. 2003). Meteoritic carbides commonly contain dissolved nitrogen, while the comparable family of nitride minerals [e.g., osbornite (TiN)] contains some dissolved carbon. This mutual limited solubility of $\mathrm{N}-\mathrm{C}$ in minerals persists through natural diamond (C), which also contains minor $\mathrm{N}$, and in the future may be useful for understanding crystallization histories and source reservoirs.

Moissanite is also relatively widely distributed as micro-crystals in the ejecta from some meteorite impact craters formed in continental crust, and it may be associated with impact diamond and a variety of iron silicides like suessite (Ernston et al. 2010). Low-pressure SiC is also found in the KT impact layer (Hough et al. 1995; Langenhorst and Deutsch 2012), though unlike impact diamond, $\mathrm{SiC}$ is not ubiquitous in crustal impact deposits (Gilmour et al. 2003). Indeed, another possibility for deep $\mathrm{SiC}$ formation, given the antiquity of some kimberlite/ diamond hosted $\mathrm{SiC}$, might be residues from giant impact processes during formation of Earth's Moon, since at that time materials from a cross-section through the upper mantle were violently exposed to the vacuum of space.

Ideal moissanite has a hexagonal structure closely related to that of lonsdaleite (and identical to wurtzite), in which every atom is tetrahedrally coordinated and corner-linked tetrahedral layers are stacked ideally in a two-layer [...ABAB ...] configuration (Fig. 5). The $\mathrm{Si}-\mathrm{C}$ distance of $1.86 \AA$ is appreciably longer than that of the carbon polymorphs because of the greater size of Si compared to C. Moissanite is known to recrystallize at temperatures between 1400 and $1600{ }^{\circ} \mathrm{C}$ to $\beta-\mathrm{SiC}$, which is cubic and similar to the diamond structure.

More than 250 stacking polytypes of $\mathrm{SiC}$ have been documented, notably hexagonal forms with 4-layer $(4 \mathrm{H})$ and 6-layer $(6 \mathrm{H}$ - the most common terrestrial polytype; Capitani et al. 2007) repeats $\{[\ldots \mathrm{ABAC} \ldots]$ and $[\ldots \mathrm{ABCACB} \ldots]$, respectively $\}$, and a rhombohedral form with a 15-layer $(15 \mathrm{R})$ sequence $[\ldots \mathrm{ABCBACABACBCACB} \ldots]$. Hundreds of other polytypes with repeat sequences from dozens to hundreds of layers (i.e., 141R and 393R) have also

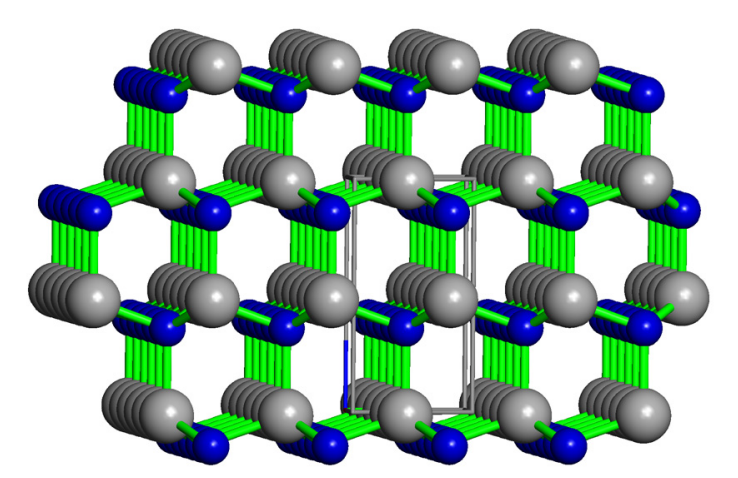

Figure 5. The moissanite $(\mathrm{SiC})$ crystal structure (hexagonal, space group $\mathrm{P}_{3} m c$; $a=3.081 \AA ; c=5.031 \AA ; Z=2$ ). Carbon and silicon atoms appear in blue and grey, respectively. 
been characterized (Krishna and Verma 1965; Lee et al. 2006; Capitani et al. 2007; Shiryaev et al. 2011; see also http://img.chem.ucl.ac.uk/www/kelly/LITERATURESICWEB.HTM\#4 an http://MinDat.org). Such complex polytypes have inspired a variety of models related to possible growth models, including screw dislocation or spiral growth mechanism (e.g., Frank 1949, 1951; Verma and Krishna 1966), the faulted matrix model (Pandey and Krishna 1975a 1975b, 1978), one-dimensional disorder theory (Jagodzinski 1954a, 1954b), and the axial nearest neighbor Ising model (Price and Yeomans 1984).

A curious crystal chemical aspect related to silicon carbide is the apparent absence of Si-C bonding in other naturally occurring compounds (Nawrocki 1997; Franz 2007; Tran et al. 2011). Chemists have explored a rich landscape of synthetic organic silanes, silanols, and silicones, but natural examples of these potentially crystal-forming compounds have not yet been described.

Cohenite. The iron carbide cohenite $\left[(\mathrm{Fe}, \mathrm{Ni}, \mathrm{Co})_{3} \mathrm{C}\right]$, also called cementite when it occurs as a binding agent in steel, is second in abundance as a natural carbide only to moissanite. In nature cohenite is known primarily as an accessory mineral from more than a dozen iron meteorites (Brett 1967), but it also occurs occasionally with native iron in the crust, for example at Disko Island in central west Greenland, and the Urals in Russia. Though iron carbides are rare in nature, the low-pressure phase behavior of carbon in iron has been studied extensively by the steel industry (e.g., Brooks 1996).

Iron carbide occurs occasionally with native iron in the crust. For example, local occurrences of metallic iron with iron carbide ("cohenite") may result from thermal interaction and reduction of basalt with coal or other carbon-rich sediments (Melson and Switzer 1966; Pederson 1979, 1981; Cesnokov et al. 1998). Most famously, Fe-Ni carbide (Ni-poor cohenite) occurs in massive native iron, with schreibersite, sulfides and a variety of minerals in graphitebearing glassy Tertiary basalts on and around Disko Island, Greenland (individual iron masses > 20 tons; Nordenskiöld 1872; Pauly 1969; Bird and Weathers 1977; Goodrich 1984; Goodrich and Bird 1985). A further 10 ton mass was discovered as recently as $1985,70 \mathrm{~km}$ away from the original Disko iron location (Ulff-Moller 1986). Comparable massive and dispersed native iron containing not only iron carbide but also silicon carbide (H-6, moissanite), occurs together with a rich variety of more than 40 minerals including native metals ( $\mathrm{Al}, \mathrm{Cu}$ ), in glass-bearing Permian doleritic sills on the Putorana Plateau, Siberia (Oleynikov et al. 1985). These occurrences are partly brecciated and, although superficially resembling meteoritic textures, they are considered to be terrestrial (Treiman et al. 2002). The origin of the Disko iron is still debated: detailed mapping of dispersed iron in regional basalts strongly favors large-scale interaction of carbonrich sediments with volcanic lavas (Larsen and Pedersen 2009). However, their correlation with basal stratigraphic units on the Nussussuaq peninsula that preserve unambiguous Ir-bearing impact spherules has reintroduced the prospect for involvement of a meteorite impact in the origin of carbon-rich Disko iron (Jones et al. 2005) as originally invoked by its discoverer (Nordenskiöld 1872).

The structure of cohenite, (orthorhombic; space group Pbnm, $a=4.518 \AA$; $b=5.069 \AA$; $c=6.736 \AA$ \& Hendricks 1930), has been extensively studied. Many samples display different cell parameters, potentially related to a variety of causes such as quenching rates. The structure is composed of regular trigonal prisms of iron atoms with carbon at the center (Fig. 6; Animation 4). (Note that in the first structure experiments it was reported that cohenite features a framework of near regular $\mathrm{CFe}_{6}$ octahedra, each with 6 iron atoms surrounding a central carbon atom. However, the positions of the carbon atoms were not determined and the assumption of octahedral coordination was incorrect.)

New carbides from Chinese ultramafic rocks. Two natural occurrences of exotic carbides deserve special note, because they point to a possibly rich and as yet largely unexplored deep

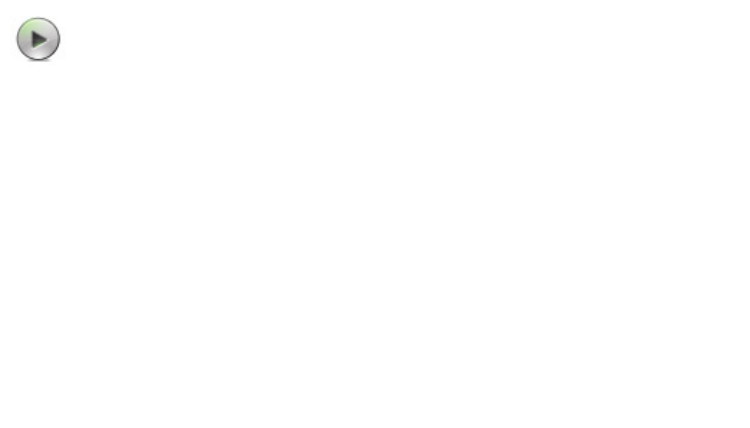

Figure 6. The structure of the iron carbide cohenite $\left[(\mathrm{Fe}, \mathrm{Ni}, \mathrm{Co})_{3} \mathrm{C}\right]$ (orthorhombic, space group Pbnm; $a$ $=4.518 \AA, b=5.069 \AA, c=6.736 \AA$ $Z=4)$. Carbon and iron atom appear in blue and gold, respectively. Animation 4: For readers of the for an amimation, click the image for an animation of the iron carbide cohenite crystal structure.]

carbide mineralogy. The first localities are associated with ultramafic rocks in Central China: (1) in podiform chromitites of the Luobusha ophiolite complex, Autonomous Tibetan Region; (2) within the Mengyin kimberlite field, Linyi Prefecture; (3) within the Yangliuping N-Cu-PGE Deposit, Sichuan Province; and (4) at Liu Village, Henan Province. These deposits incorporate minor amounts of three carbides that are unknown from any other region: qusongite (WC; Fang et al. 2009; Shi et al. 2009), yarlongite [ $\left(\mathrm{Fe}_{4} \mathrm{Cr}_{4} \mathrm{Ni}\right) \mathrm{C}_{4}$; Nicheng et al. 2005, 2008], and tongbaite $\left(\mathrm{Cr}_{3} \mathrm{C}_{2}\right.$; Tian et al. 1983; Dai et al. 2004). The association of these carbides with moissanite, cohenite, and khamrabaevite $[(\mathrm{Ti}, \mathrm{V}, \mathrm{Fe}) \mathrm{C}]$, as well as other dense, high-temperature phases such as diamond, coesite (a high-pressure form of $\mathrm{SiO}_{2}$ ), and varied native metals, including $\mathrm{Fe}$, $\mathrm{Ni}, \mathrm{W}, \mathrm{Cr}, \mathrm{Pb}$, and $\mathrm{W}$, points to a high-temperature, high-pressure origin in a reduced mantle environment (Robinson et al. 2001; Shi et al. 2009).

New carbides from placer deposits of the Urals. A second enigmatic carbide region is found in the Ural Mountains of Russia, within both the Avorinskii Placer, Baranchinsky Massif, and in sediments of the Neiva River near Verkhneivinsk. Placer deposits have yielded $<0.3$ mm-diameter grains of isovite $\left[(\mathrm{Cr}, \mathrm{Fe})_{23} \mathrm{C}_{6}\right.$; Generalov et al. 1998], as well as euhedral crystals from the complex nonstoichiometric solid solution between niobocarbide and tantalocarbide [(Nb,Ta) $\mathrm{C}_{1-x} ;$ Gusev et al. 1996; Novgorodova et al. 1997]. All known specimens of the latter two minerals, however, were collected early in the $20^{\text {th }}$ century and the exact location of the placer deposit is currently unknown. These two possibly related placer deposits produce an enigmatic suite of other unusual minerals, including native rhenium and osmium (both with melting temperatures $\left.>3000{ }^{\circ} \mathrm{C}\right)$, anyuite $\left[\mathrm{Au}(\mathrm{Pb}, \mathrm{Sb})_{2}\right]$, and jedwabite $\left[\mathrm{Fe}_{7}(\mathrm{Ta}, \mathrm{Nb})_{3}\right]$. The source lithologies and paragenesis of these minerals are not known, though the concentration of $\mathrm{Nb}$ and Ta suggests a possible association with carbonatitic magmas. In any case, they point to the potential diversity of rare carbides in unusual geochemical environments.

\section{Rhombohedral carbonates}

By far the most abundant carbon-bearing minerals, both in the number of different species and in their total crustal volume, are the carbonates, of which more than 300 have received IMA approval (http://rruff.info/ima/; Fig. 7). Several previous compilations have reviewed carbonate minerals in detail (Reeder 1983a; Klein and Hurlbut 1993; Chang et al. 1997). Here we summarize key aspects of the mineralogy and crystal chemistry of select carbonates (Tables 5 and 6). Almost all of these minerals incorporate near-planar $\left(\mathrm{CO}_{3}\right)^{2-}$ anions, with an equilateral triangle of oxygen atoms around the central carbon atom. Most $\mathrm{C}-\mathrm{O}$ bond distances are between 1.25 and $1.31 \AA$ and O-C-O angles are close to $120^{\circ}$. Rigid-body libration of these molecular anions contributes to distinctive characteristics of carbonate vibrational spectra, notably three prominent infrared absorption features at $\sim 690-750,840-900$, and $1400-1490 \mathrm{~cm}^{-1}$ (Adler and Kerr 1963; White 1974; Chang et al. 1997) and the strong symmetric stretching modes found near $1100 \mathrm{~cm}^{-1}$ in Raman spectra (Rutt and Nicola 1974). 


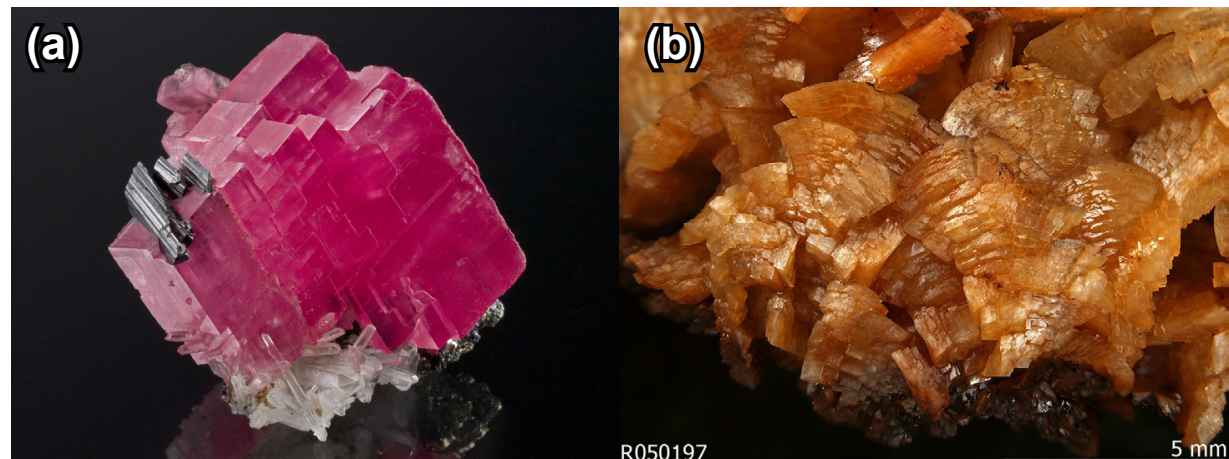

(ब)

(d)
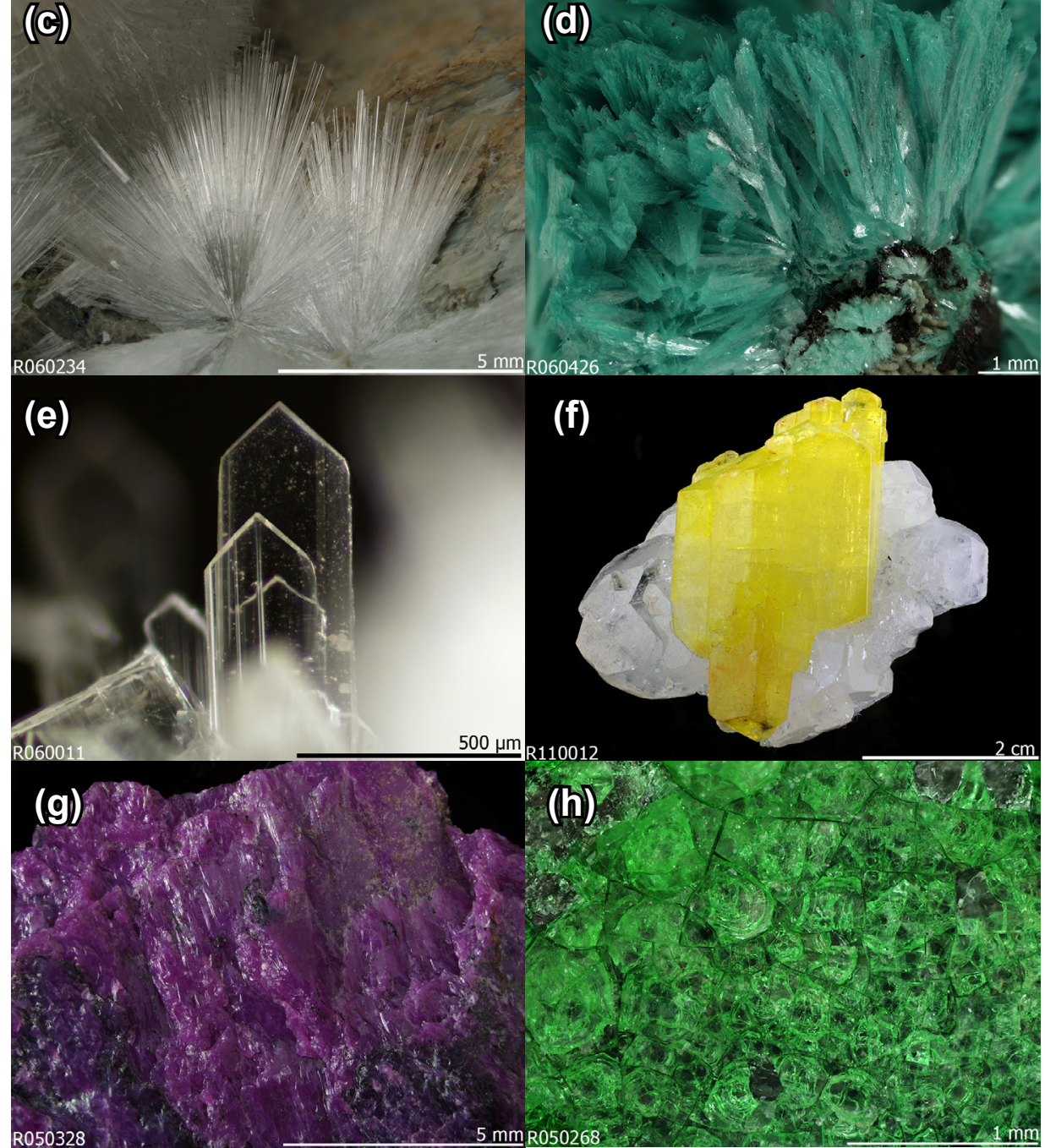

Figure 7. (caption on facing page)
Two types of rhombohedral carbonates-the calcite and dolomite groups-collectively represent by far the most abundant carbonate minerals in Earth's crust, with calcite $\left(\mathrm{CaCO}_{3}\right)$ and dolomite $\left[\mathrm{CaMg}\left(\mathrm{CO}_{3}\right)_{2}\right]$ in massive sedimentary and metamorphic formations accounting for at least $90 \%$ of crustal carbon (Reeder 1983b). Orthorhombic carbonates in the aragonite group also play a significant role in Earth surface processes (Speer 1983), particularly through biomineralization (Stanley and Hardie 1998; Dove et al. 2003; Knoll 2003). These three groups are surveyed below.

Calcite and the calcite group. The most important carbonate minerals belonging to the calcite group (Table 5; Reeder 1983b) include calcite $\left(\mathrm{CaCO}_{3}\right)$, magnesite $\left(\mathrm{MgCO}_{3}\right)$, rhodocrosite $\left(\mathrm{MnCO}_{3}\right)$, siderite $\left(\mathrm{FeCO}_{3}\right)$, and smithsonite $\left(\mathrm{ZnCO}_{3}\right)$. It should be emphasized that these minerals seldom occur as pure end-members, but instead commonly form solid solutions with many divalent cations. The calcite structure (space group $R \overline{3} c$; e.g., Bragg 1914; Effenberger et al. 1981; Chang et al. 1997) has a topology similar to that of $\mathrm{NaCl}$, with each $\mathrm{Ca}^{2+}$ coordinated to $6\left(\mathrm{CO}_{3}\right)^{2-}$ groups, and each $\left(\mathrm{CO}_{3}\right)^{2-}$ group in turn coordinated to 6 $\mathrm{Ca}^{2+}$ cations. However, the orientations of the $\left(\mathrm{CO}_{3}\right)^{2-}$ groups, while the same within each layer, are $180^{\circ}$ out of phase in successive layers, thus doubling the repeat distance in the $c$ axial direction relative to a sodium chloride analog. Note that this layer-by-layer alternation of $\left(\mathrm{CO}_{3}\right)^{2-}$ group orientations results in an oxygen atom distribution that approximates hexagonal close packing, with $\mathrm{C}$ and $\mathrm{Ca}$ occupying 3- and 6-coordinated interstices, respectively (Megaw 1973). The flattened shape of this carbonate anion results in an obtuse rhombohedral angle of $101^{\circ} 55^{\prime}$ (Fig. 8; Animation 5).
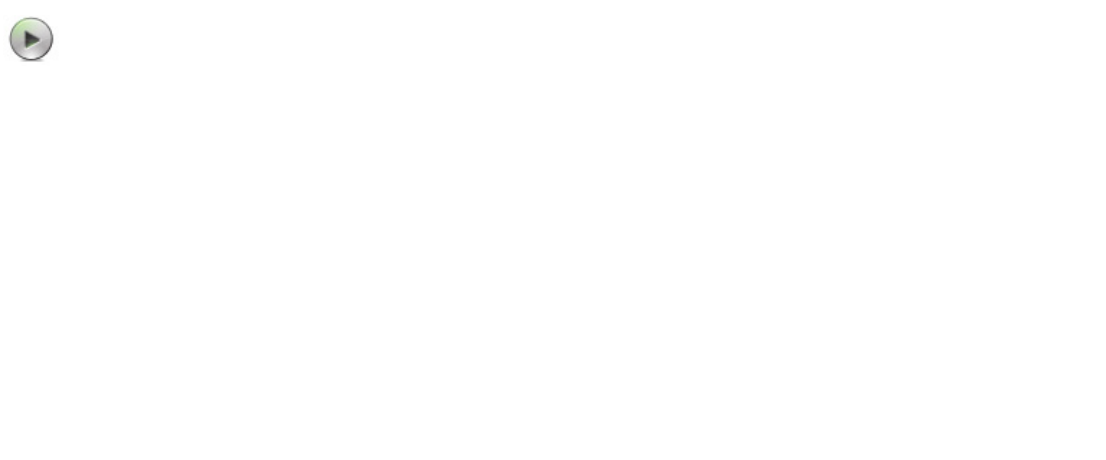

Figure 8. The structure of calcite $\left(\mathrm{CaCO}_{3}\right)$ (rhombohedral; space group $R \overline{3} c$; hexagonal setting $a=$ $4.989 \AA ; c=17.061 \AA ; Z=6$; rhombohedral setting $a=6.375 ; \alpha=46.1^{\circ} ; Z=2$ ). Calcite crystal from Elmwood Mine, Carthage, Tennessee. Photo courtesy of Rob Lavinsky. [Animation 5: For readers of the electronic version, click the image for an animation of the calcite crystal structure.]

Figure 7. (figure on facing page) The diversity of carbonate minerals. (a) Rhodochrosite $\left(\mathrm{MnCO}_{3}\right)$, rhombohedral crystals from the Home Sweet Home Mine, Mount Bross, Alma District, Park County, Colorado, USA. (b) Ankerite $\left[\mathrm{CaFe}^{2+}\left(\mathrm{CO}_{3}\right)_{2}\right]$ from Brownley Hill mine, Nenthead, Cumbria, England showing the typical curved saddle-shaped rhombohedral crystals. (c) Artinite $\left[\mathrm{Mg}_{2} \mathrm{CO}_{3}(\mathrm{OH})_{2} \cdot 3 \mathrm{H}_{2} \mathrm{O}\right]$, divergent sprays of clear colorless acicular crystals from San Benito County, California, USA. (d) Aurichalcite $\left[\mathrm{Zn}_{5}\left(\mathrm{CO}_{3}\right)_{2}(\mathrm{OH})_{6}\right]$, divergent sprays of light blue lathlike crystals from Bisbee, Cochise County, Arizona, USA. (e) Hydromagnesite $\left[\mathrm{Mg}_{5}\left(\mathrm{CO}_{3}\right)_{4}(\mathrm{OH})_{2} \cdot 4 \mathrm{H}_{2} \mathrm{O}\right]$, colorless bladed crystals from Paradise Range, Nye County, Nevada, USA. (f) Jouravskite $\left[\mathrm{Ca}_{3} \mathrm{Mn}^{4+}\left(\mathrm{SO}_{4}\right)\left(\mathrm{CO}_{3}\right)(\mathrm{OH})_{6} \cdot 12 \mathrm{H}_{2} \mathrm{O}\right]$, yellow hexagonal prism associated with calcite from the Wessels mine, Kurumen, Kalahari Manganese fields, Cape Province, South Africa. (g) Stichtite $\left[\mathrm{Mg}_{6} \mathrm{Cr}_{2} \mathrm{CO}_{3}(\mathrm{OH})_{16} \cdot 4 \mathrm{H}_{2} \mathrm{O}\right.$ ], an aggregate of contorted purple plates from Dundas, Tasmania, Australia, (h) Zaratite $\left[\mathrm{Ni}_{3} \mathrm{CO}_{3}(\mathrm{OH})_{4} \cdot 4 \mathrm{H}_{2} \mathrm{O}\right]$, green amorphous crust, intimately associated with népouite from Lord Brassy mine, Tasmania, Australia. All photos courtesy of the RRUFF project and irocks.com 

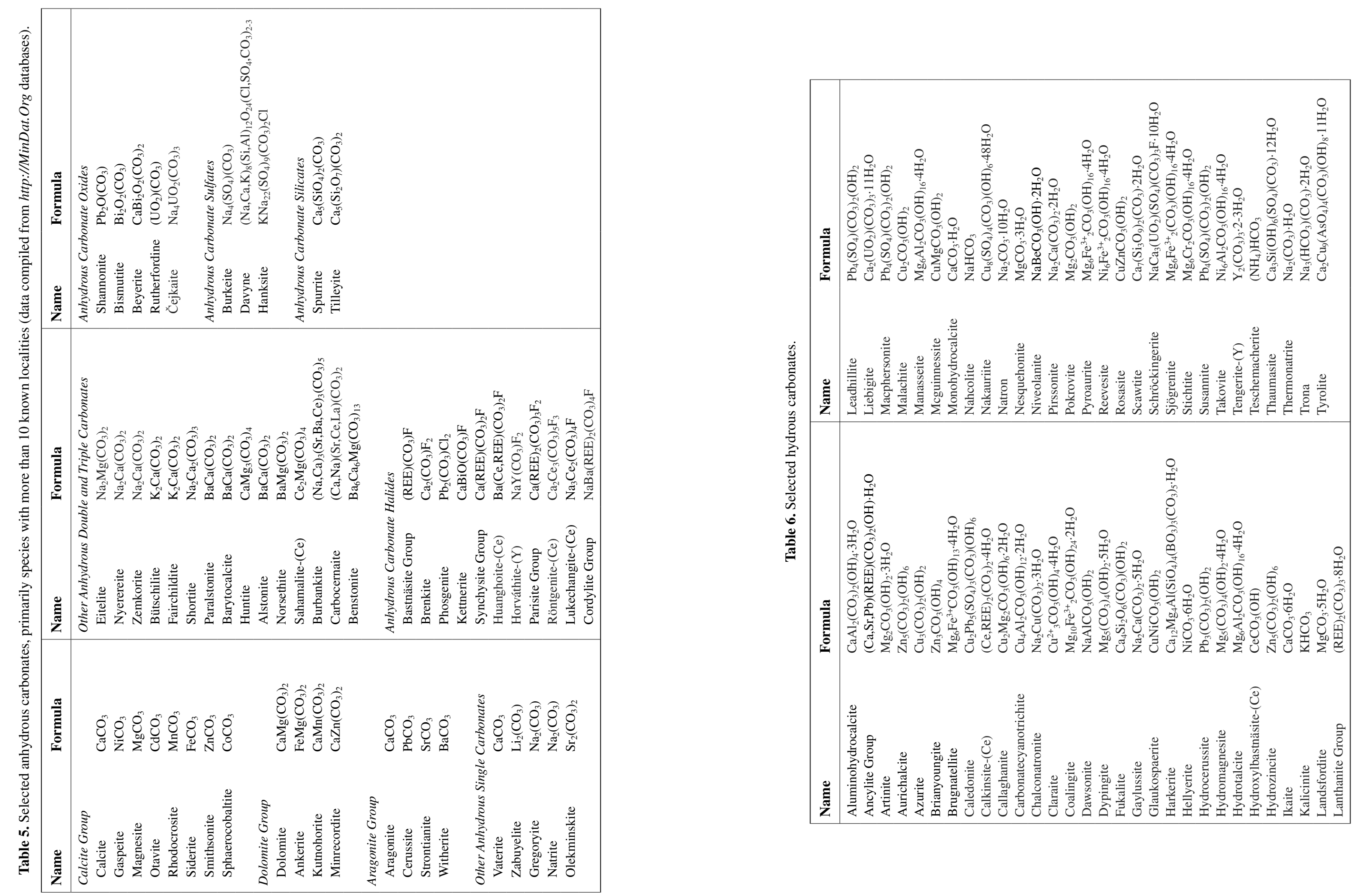
Calcite is widely distributed in Earth's crust; it appears most commonly within sedimentary rocks, where it occurs as the principal mineral of limestone, and as a natural cementing agen in many siliceous sandstone and shale units that were deposited under marine conditions. Calcite also dominates some metamorphic rocks such as marble and calcareous gneiss; occurs widely in hydrothermal systems, where it forms extensive vein networks; and is common in some unusual carbonate-rich igneous rocks such as carbonatites (Jones et al. 2013).

Although widely formed under Earth's near-surface conditions, distributions of calcite and other rhombohedral carbonate minerals have varied significantly through Earth history, principally as a consequence of feedbacks between the geosphere and biosphere (Knol 2003; Hazen et al. 2008; Hazen et al. 2013). At present, the majority of calcium carbonate deposition occurs as calcite precipitated within shallow marine settings. In these settings, magnesium-whose concentration is nearly $4 \times$ that of calcium in normal marine fluids - is readily incorporated into the calcite crystal lattice, with $\mathrm{Mg}$ concentrations of marine calcites equal to a few to nearly $20 \mathrm{~mol} \% \mathrm{MgCO}_{3}$ (MacKenzie et al. 1983; Morse and MacKenzie 1990; Morse et al. 2006; Berner and Berner 2012). Such Mg-bearing calcites are commonly referred to as magnesian calcite or "high $\mathrm{Mg}$ calcite" (HMC) and are distinguished from calcites with low Mg concentrations ("low Mg calcite" or LMC). Magnesium is one of a suite of divalent ions that readily co-precipitate with calcium in the calcite lattice. Because ionic coprecipitation reflects a combination of the ionic availability, temperature, and lattice structure, and because it can substantially affect the solubility and rate of dissolution of the resultant calcite, differential co-precipitation of ions within calcite has been, and continues to be, a subject of intense investigation as a means of unraveling the geologic history of the oceanic system (Morse and Mackenzie 1990).

One of calcite's remarkable and as yet largely unexplored features is its extraordinary range of crystal forms (e.g., Dana 1958). Habits range from the more common rhombohedral and scalenohedral crystal forms, to needle-like, platy, and equant shapes with expression of a least 300 different documented crystal forms (Fig. 9; see also specimen photographs on http:// MinDat.org). Some of the most varied crystal habits are widely distributed in association with both biological skeletalization (Fallini et al. 1996; Dove et al. 2003) and speleogenesis (Frisia et al. 2000) and reflect a complex array of physical, chemical, and biological influences during crystallization. Because calcite crystal morphology is strongly affected by the kinetics of crystal growth, unraveling the differential effects of fluid saturation state, carbonate ion availability, ionic activity, the presence or absence of ionic inhibitors to nucleation and growth and even the presence or absence of mineral catalyzing organic molecules (e.g., Cody and Cody 1991; Teng and Dove 1997; Teng et al. 1998; Orme et al. 2001), is critical to reveal as of yet untapped insights to Earth's crustal evolution. This need to document connections between environment and crystal form may be true, in particular, for our understanding of distinct carbonate morphologies such as "herringbone" calcite (Sumner and Grotzinger 1996; Kah et al. 1999) and "molar-tooth" calcite (Pollock et al. 2006) that show distinct environmental distributions through Earth history (see Hazen et al. 2013).

Other calcite group minerals. The magnesium carbonate magnesite $\left(\mathrm{MgCO}_{3}\right)$ forms primarily through alteration of $\mathrm{Mg}$-rich igneous and metamorphic rocks, commonly in association with serpentine, as well as by direct precipitation from $\mathrm{Mg}$-rich solutions and as a primary phase in mantle-derived carbonatites. Anhydrous magnesium carbonate commonly hydrates to form one of several secondary minerals (Table 6), including hydromagnesite $\left[\mathrm{Mg}_{4}\left(\mathrm{CO}_{3}\right)_{3}(\mathrm{OH})_{2} \cdot 3 \mathrm{H}_{2} \mathrm{O}\right]$, artinite $\left[\mathrm{Mg}_{2} \mathrm{CO}_{3}(\mathrm{OH})_{2} \cdot 3 \mathrm{H}_{2} \mathrm{O}\right]$, dypingite $\left[\mathrm{Mg}_{5}\left(\mathrm{CO}_{3}\right)_{4}(\mathrm{OH})_{2} \cdot 5 \mathrm{H}_{2} \mathrm{O}\right]$, pokrovite $\left[\mathrm{Mg}_{2} \mathrm{CO}_{3}(\mathrm{OH})_{2}\right]$, nesquehonite $\left(\mathrm{MgCO}_{3} \cdot 3 \mathrm{H}_{2} \mathrm{O}\right)$, and landsfordite $\left(\mathrm{MgCO}_{3} \cdot 5 \mathrm{H}_{2} \mathrm{O}\right)$.

Rhodochrosite, the manganese carbonate $\left(\mathrm{MnCO}_{3}\right)$, most commonly occurs as a veinfilling phase in hydrothermal ore districts. Limited solid solutions with $\mathrm{Ca}, \mathrm{Fe}$, and $\mathrm{Mg}$ endmembers, as well as $\mathrm{Zn}, \mathrm{Ba}$, and $\mathrm{Pb}$, are typical, as is partial alteration to manganese oxide
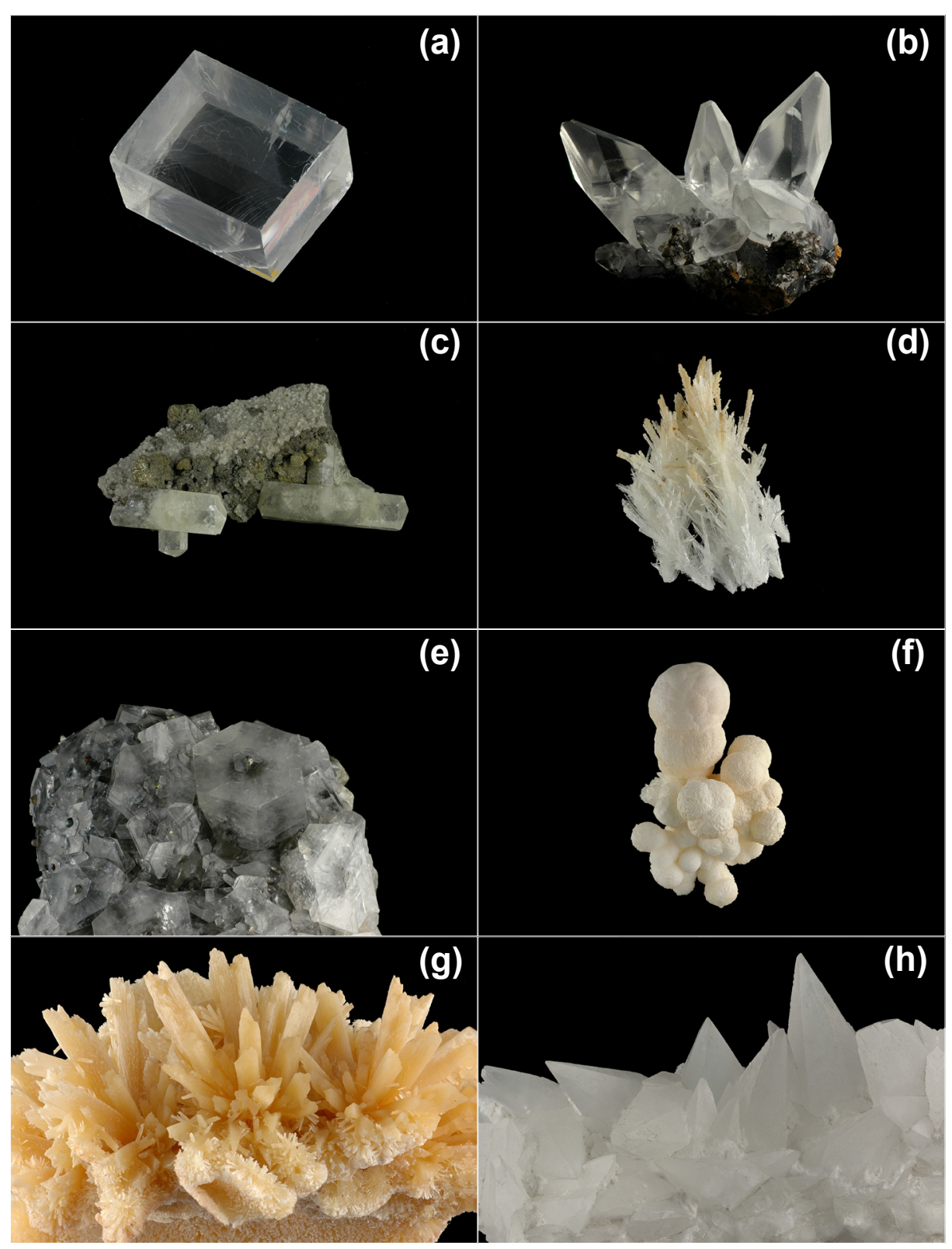

Figure 9. Crystal forms of natural calcite. (a) Rhombohedral cleavage fragment of optical grade material from near Presidio, Texas, USA, University of Arizona Mineral Museum 16674 (b) Scalenohedrons collected in the early 1800's from the Bigrigg mine, Cumbria, England. Bob Downs specimen; (c) Hexagonal prisms with rhombohedral terminations from Joplin, Missouri, USA UAMM 16545; (d) Herringbone growths of acicular crystals from the Southwest mine, Bisbee, Arizona, USA, UAMM 9499; (e) Hexagonal prism with pyrite centers from Charcas, San Luis Potosi, Mexico, UAMM 1214; (f) Stalactite globules from Southwest mine, Bisbee, Arizona, USA, UAMM 9499; (g) Aggregate of bladed crystals from the Onyx cave, Santa Rita Mts, Arizona, USA, UAMM 5503; (h) Hexagonal prisms with pyramidal termination from thje Camp Bird mine, Imogene Basin, Ouray County, Colorado, USA, UAMM 6703. All photograph by Alesha Siegal, University of Arizona. 
hydroxides. Rhodochrosite is typically pale pink in color, though relatively rare deep rose pink specimens occur occasionally and are highly prized as semi-precious gemstones.

The iron carbonate siderite $\left(\mathrm{FeCO}_{3}\right)$ occurs in massive beds as an important component of some Precambrian banded iron sedimentary formations (Klein 2005), as well as in hydrothermal veins associated with ferrous metal sulfides. Siderite commonly incorporates $\mathrm{Ca}, \mathrm{Mn}$, and $\mathrm{Co}$, and it forms a complete solid solution with magnesite in a variety of lithological settings, as well as with smithsonite $\left(\mathrm{ZnCO}_{3}\right)$ in hydrothermal lead-zinc ore deposits. Siderite is only stable under conditions of relatively low $f_{\mathrm{O}_{2}}$ (Hazen et al. 2013). It is metastable under ambient oxic conditions and typically decomposes to a suite of iron oxide-hydroxides such as goethite $[\mathrm{FeO}(\mathrm{OH})]$, and related hydrous phases $\left[\mathrm{FeO}(\mathrm{OH}) \cdot n \mathrm{H}_{2} \mathrm{O}\right]$ —reactions that are accelerated by chemolithoautotrophic microbial activity.

Dolomite group. The dolomite group ( $\operatorname{space}$ group $R \overline{3}$ ) is topologically identical to calcite, but in these double carbonate minerals two or more different cations occupy alternate layers perpendicular to the $c$ axis (Wasastjerna 1924; Wyckoff and Merwin 1924; Reeder 1983b; Chang et al. 1997; Fig. 10; Animation 6). Important end-member minerals in this group (Table 5) include dolomite $\left[\mathrm{CaMg}\left(\mathrm{CO}_{3}\right)_{2}\right]$, ankerite $\left[\mathrm{FeMg}\left(\mathrm{CO}_{3}\right)_{2}\right]$, kutnohorite $\left[\mathrm{CaMn}\left(\mathrm{CO}_{3}\right)_{2}\right]$, and minrecordite $\left[\mathrm{CaZn}\left(\mathrm{CO}_{3}\right)_{2}\right]$. Note that in both the calcite and dolomite mineral groups the $\left(\mathrm{CO}_{3}\right)^{2-}$ anions lie perpendicular to the rhombohedral $c$ axis and they librate with a helical motion along this axis (Gunasekaran et al. 2006; Fig. 11; Animation 7]).

The planar orientation of the $\mathrm{CO}_{3}{ }^{2-}$ anions in the calcite and dolomite group minerals results in many of their distinctive properties, for example in their extreme optical anisotropy (maximum and minimum refractive indices differ by $\sim 0.2$ in these minerals), which causes the familiar double refraction seen through calcite cleavage rhombohedra. The near-perfect [104] cleavage of calcite and dolomite group minerals also arises from anisotropies in bonding; this cleavage plane results in the minimum number of broken $\mathrm{Ca}-\mathrm{O}$ bonds and no broken $\mathrm{C}-\mathrm{O}$ bonds. Strong bonding in the plane parallel to the $\mathrm{CO}_{3}{ }^{2-}$ anions (i.e., the $a$ axis of the hexagonal setting) compared to weaker $\mathrm{Ca}-\mathrm{O}$ bonds in the perpendicular direction (the $c$ axis of the hexagonal setting) leads to extreme anisotropy in calcite's thermal expansion, as well. The $c$-axis thermal expansion is positive $\sim+3.2 \times 10^{-5}{ }^{\circ} \mathrm{C}^{-1}$, whereas $a$-axis thermal expansion

(a)

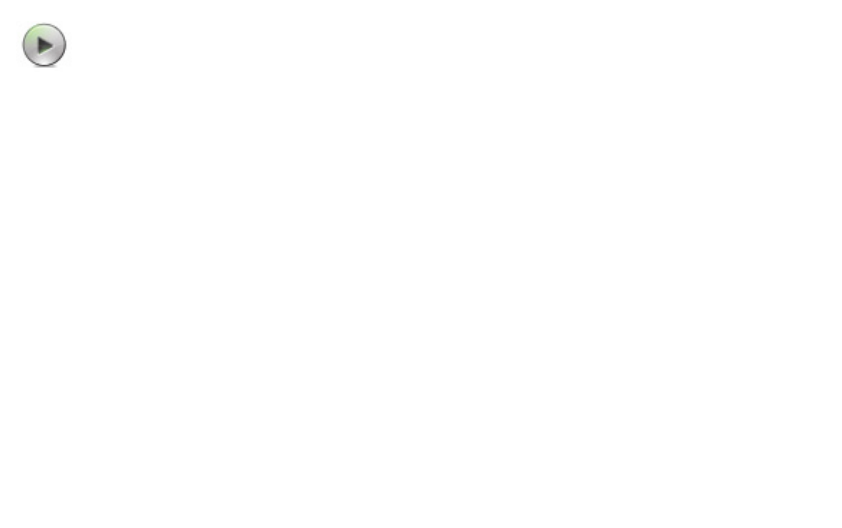

Figure 10. Dolomite. (a) The structure of dolomite $\left[\mathrm{MgCa}\left(\mathrm{CO}_{3}\right)_{2}\right]$ (rhombohedral; space group $R \overline{3}$; hexagonal setting $a=4.807 \AA ; c=16.00 \AA ; Z=3$; rhombohedral setting $a=6.015, \alpha=47.1^{\circ} ; Z=1$ ). Blue spheres are carbon atoms, with light green $\mathrm{CaO}_{6}$ octahedra and dark green $\mathrm{MgO}_{6}$ octahedra. (b) Dolomite crystals reflect their rhombohedral crystal structure. [Animation 6: For readers of the electronic version, click the image for an animation of the dolomite crystal structure.]

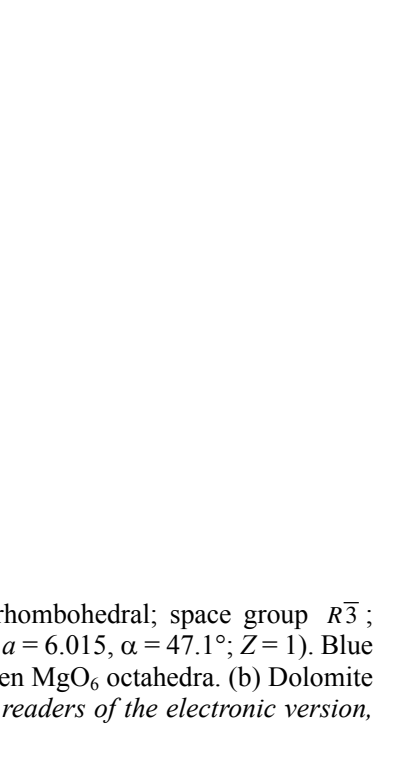

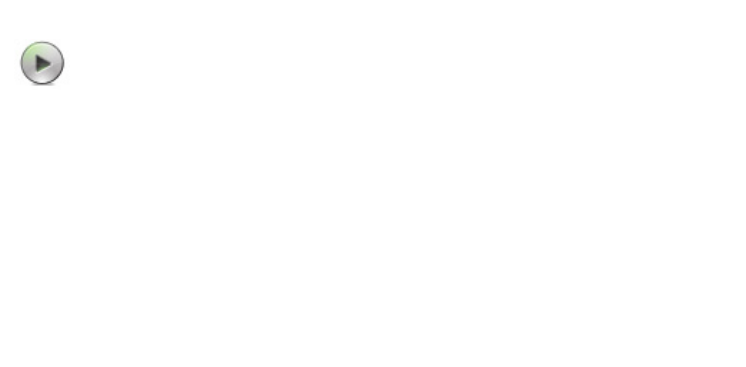

Figure 11. The rigid body librating $\mathrm{CO}_{3}^{2-}$ unit of the calcite and dolomite mineral groups. Blue and oxygen atoms, respectively. [Animation 7. For readers of the electronic version, click the image for an animation with librating for an $\mathrm{CO}_{3}{ }^{2-}$.]

is negative $\sim-0.3 \times 10^{-5}{ }^{\circ} \mathrm{C}^{-1}$ (Markgraf and Reeder 1985). Note, however, that in magnesite and dolomite the shorter, stronger Mg-O bonds result in thermal expansion that is positive in both $a$ - and $c$-axial directions.

Dolomite is by far the most abundant species among the dolomite group minerals. It forms primarily within both sedimentary and metamorphic deposits through the diagenetic replacement of calcite during interaction with $\mathrm{Mg}$-rich fluids. Phase relations in the $\mathrm{CaCO}_{3}$ $\mathrm{MgCO}_{3}-\mathrm{FeCO}_{3}$ system, including the phases calcite, magnesite, siderite, and dolomite, as well as magnesian calcite, as summarized by Chang et al. (1997), reveal extensive regions in pressure-temperature-composition space of coexisting calcite group and dolomite group minerals-a topology that is borne out by the common association of calcite and dolomite in sedimentary rocks.

Ankerite and kutnahorite are $\mathrm{Fe}^{2+}$ - and $\mathrm{Mn}^{2+}$-bearing dolomites, respectively, with nearcontinuous solid solutions observed among the $\mathrm{Mg}, \mathrm{Fe}$, and Mn end-members (Essene 1983). These phases occur most commonly as a result of hydrothermal alteration of calcite by reduced fluids rich in $\mathrm{Fe}^{2+}$ and $\mathrm{Mn}^{2+}$.

\section{The aragonite group}

A large number of $\mathrm{CaCO}_{3}$ polymorphs enrich carbonate mineralogy (Carlson 1983; Chang et al. 1997). The aragonite group, which includes the aragonite form of $\mathrm{CaCO}_{3}$ plus cerussite $\left(\mathrm{PbCO}_{3}\right)$, strontianite $\left(\mathrm{SrCO}_{3}\right)$, and witherite $\left(\mathrm{BaCO}_{3}\right)$, prevail in carbonates that contain cations with ionic radii as large or larger than calcium. The crystal structure of aragonite (Speer 1983; Fig. 12; Animation 8), first determined by Bragg (1924), is orthorhombic with the standard space group Pnam (with $c<a<b$ ). However, the structure is more conveniently described in a non-standard orientation with $a<c<b$, resulting in space group Pmcn. The structure in this orientation possesses alternating (001) layers of divalent metal cations and $\left(\mathrm{CO}_{3}\right)^{2-}$ anions. Two types of $\left(\mathrm{CO}_{3}\right)^{2-}$ layers $\left(\mathrm{C}_{1}\right.$ and $\left.\mathrm{C}_{2}\right)$ alternate with two orientations of metal cations $(\mathrm{A}$ and $\mathrm{B})$ in a stacking sequence $\left[\ldots \mathrm{AC}_{1} \mathrm{BC}_{2} \ldots\right]$ (Speer 1983). Each $\left(\mathrm{CO}_{3}\right)^{2-}$ anion is coordinated to 6 divalent metal atoms, and each metal atom is coordinated to 9 oxygen atoms (Fig. 12a).

Aragonite is a denser polymorph of $\mathrm{CaCO}_{3}$ than calcite $\left(2.95 \mathrm{vs} .2 .71 \mathrm{~g} / \mathrm{cm}^{3}\right)$, and has been recognized as a mineral characteristic of relatively high-pressure, low-temperature metamorphic environments (McKee 1962; Coleman and Lee 1962; Ernst 1965). Aragonite, however, is also one of the predominant carbonate minerals-along with calcite and dolomite-that comprise the vast amount of carbon mineralization in Earth's surface environments. Although aragonite is the least stable of these minerals, and undergoes rapid recrystallization to thermodynamically more stable forms, it has been recognized as a fundamental constituent of marine depositional environments since at least the Archean (Sumner and Grotzinger 2004), and represents a primary shallow-marine depositional facies throughout the Proterozoic (Grotzinger and Read 1983; Bartley and Kah 2004; Kah and Bartley 2011). Furthermore, since the onset of enzymatic 
(a)

(

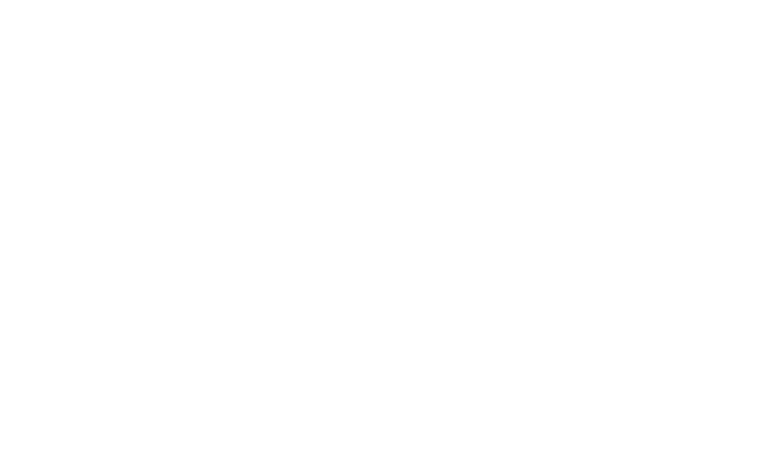

(b)
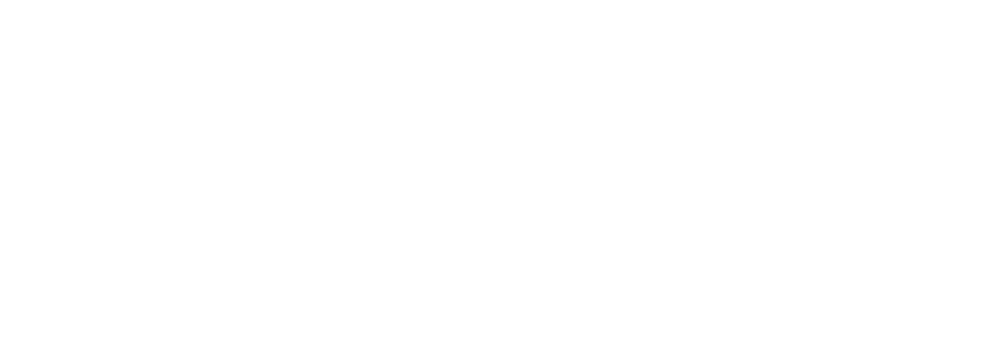

Figure 12. Aragonite Group. (a) The structure of aragonite $\left(\mathrm{CaCO}_{3}\right)$ (orthorhombic; space group Pmcn; $a=4.960 \AA ; b=7.964 \AA ; c=5.738 \AA ; Z=4$ ). Blue spheres are carbon atoms, whereas green polyhedra are $\mathrm{CaO}_{9}$ groups. (b) The orthorhombic structure of aragonite is manifest in its common crystal forms, including tabular crystals from Tazouta Mine, Sefrou, Morocco (left) and acicular crystals from Transvall, South Africa. Photos courtsey of Rob Lavinski. [Animation 8: For readers of the electronic version, click the image for an animation of the aragonite crystal structure.]

biomineralization, more than 500 million years ago, aragonite has been a primary constituent of the fossil record, forming metastable skeletons of some calcareous algae (Bathurst 1976) as well as the skeletal components of a variety of invertebrates, including a wide variety of molluscs, scleractinian corals, and some bryozoans (Cloud 1962; Rucker and Carver 1969; Knoll 2003; Dove 2010). Three other aragonite group minerals, the $\mathrm{Sr}, \mathrm{Ba}$, and $\mathrm{Pb}$ carbonates strontianite, witherite, and cerussite, respectively, are all found primarily in relatively low-temperature hydrothermal or supergene environments, commonly associated with sulfates and metal sulfide ores (Smith 1926; Mitchell and Pharr 1961; Mamedov 1963; Speer 1977; Dunham and Wilson 1985; Wang and Li 1991). Strontianite, in particular, has also been found in association with enzymatic biomineralization, with strontianite comprising nearly $40 \%$ of the skeletal carbonate in some scleractinian corals (McGreegor et al. 1997), although it is uncertain whether strontianite in this case is primary or an early diagenetic phase resulting from recrystallization along the metastable strontianite-aragonite solid solution (Plummer et al. 1992).

Phase diagrams for the aragonite polymorphs of $\mathrm{CaCO}_{3}$ and other calcite group minerals underscore the effects of divalent cation coordination number on carbonate structure type Several calcite group minerals transform to the aragonite structure at high pressure (Carlson 1983; Yoshioka and Kitano 2011); conversely, the aragonite group minerals strontianite and witherite transform to the calcite structure at high temperature (Chang 1965).

\section{Other anhydrous carbonates}

More than 90 anhydrous carbonates other than the above mentioned rhombohedral and orthorhombic species have been described, though only a handful of these diverse phases are common (Table 5; http://rruff.info/ima/). Of these minerals, vaterite, huntite, and several minerals associated with carbonatites deserve special note.

Vaterite. Vaterite is a polymorph of $\mathrm{CaCO}_{3}$ that is unstable under ambient conditions, yet plays an important role in biomineralization. Nanocrystalline vaterite rapidly converts to calcite, but can be stabilized indefinitely by a variety of hydrophilic organic molecules. Vaterite's critical role in biomineralization arises from the low energy required for its conversion to other crystalline forms (Xu et al. 2006; Soldati et al. 2008; Wehrmeister et al. 2012). Therefore, it is the preferred mineral phase (along with amorphous calcium carbonate, or ACC) for storing material critical to skeletal growth. Typically, metazoans process nanaggregates of vaterite (or ACC; Addadi et al. 2003) to form mesoscale syntaxial structures, which may provide an energetically favorable pathway to the construction of larger skeletal elements (e.g., single-crystal echinoderm plates).

Details of the vaterite crystal structure, which must be analyzed using nano-scale powders by X-ray or electron diffraction methods, remains in doubt. It was once thought to be hexagonal (space group $P 6_{3} / m m c ; a=7.135 \AA ; c=16.98 \AA$; Kahmi 1963). However, Le Bail et al. (2011) found evidence for an orthorhombic structure with 3-fold cyclic twinning (space group Ama2; $a=8.472 \AA ; b=7.158 \AA ; c=4.127 \AA ; Z=4$ ). By contrast, Mugnaioli et al. (2012) propose a monoclinic unit cell ( $a=12.17 \AA, b=7.12 \AA, c=9.47 \AA, \beta=118.94^{\circ}$ ), which is a geometric transformation of the smallest hexagonal cell proposed by Kamhi (1963). All studies agree that vaterite features $\mathrm{Ca}$ in distorted 7 or 8 coordination, with an octahedron of $6 \mathrm{Ca}-\mathrm{O}$ bonds at $\sim 2.4 \AA$, and two longer $\mathrm{Ca}-\mathrm{O}$ bonds at $>2.9 \AA$ (Fig. 13; Animation 9). Thus, calcium coordination in vaterite is intermediate between that of calcite (6) and aragonite (9). Wang and Becker (2009) employed first-principles calculations and molecular dynamics simulations to elucidate details of the vaterite structure and $\mathrm{CO}_{3}{ }^{2-}$ group orientations. Previous studies had suggested rotational disorder among carbonate groups, but Wang and Becker (2009) demonstrate a more stable configuration with an ordered $\mathrm{CO}_{3}{ }^{2-}$ superstructure. Vaterite is commonly rotationally disordered when first crystallized, but it can achieve carbonate orientational order through annealing.

Huntite. Huntite $\left[\mathrm{CaMg}_{3}\left(\mathrm{CO}_{3}\right)_{4}\right]$ occurs as a low-temperature mineral, both by direct precipitation from aqueous solutions enriched in $\mathrm{Mg}$ and as an alteration product of dolomite or magnesite (Kinsman 1967). Its hexagonal structure (space group $R 32 ; a=9.503 \AA ; c=$ $7.821 \AA$ ) bears some similarities to rhombohedral carbonates. Magnesium is in octahedral

$\bullet$

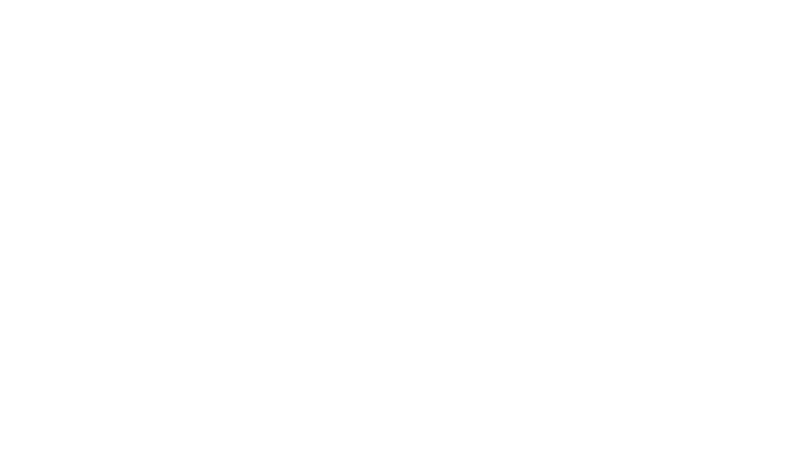

Figure 13. The crystal structure of vaterite $\left(\mathrm{CaCO}_{3}\right)$. (hexagonal, space group $P 6_{3} / m m c ; a=7.135 \AA ;$ $=16.98 \AA ; Z=16$ ). Blue spheres and green polyhedral represent carbon and calcium-oxygen polyhedral, respectively. [Animation 9: For readers of the electronic version, click the image for an animation of the vaterite crystal structure. 
coordination in all of these carbonates, but calcium in huntite is in trigonal prismatic coordination, as opposed to octahedral coordination in calcite, dolomite, and other species (Dollase and Reeder 1986; Fig. 14 [Animation 10]).

Carbonatite carbonate mineralogy. Finally, a number of exotic carbonate minerals are found associated with carbonatites, which are defined as igneous rocks (extrusive or intrusive) with greater than 50\% carbonate minerals (Tuttle and Gittins 1966; Bell 1989; Jones et al. 2013). These rare mantle-derived magmas are stable over a wide temperature range and can erupt as remarkably cool surface lavas at $\sim 500$ to $600{ }^{\circ} \mathrm{C}$ (Dawson et al. 1990; Church and Jones 1995). Carbonatites encompass a range of compositions, including those dominated by calcite $(\mathrm{Ca})$, dolomite $(\mathrm{Ca}-\mathrm{Mg})$, ankerite $(\mathrm{Ca}-\mathrm{Fe})$, and alkali $(\mathrm{Na}-\mathrm{K}+\mathrm{Ca})$ carbonate minerals. Furthermore, these magmas are often enriched in an unusual suite of elements in addition to carbon: alkalis, alkaline earths, fluorine, phosphorus, rare earth elements, and niobium (Deans 1966). As a result of these chemical complexities, approximately 30 different carbonate minerals have been identified from these varied sources (Kapustin 1980; Chang et al. 1997).

Several of the rhombohedral carbonates are found commonly in carbonatites, including calcite, magnesite, siderite, rhodochrosite, and dolomite, as well as orthorhombic aragonite and strontianite (Garson and Morgan 1978; Kapustin 1980; Dziedzic and Ryka 1983). These familiar minerals are accompanied by a number of exotic double carbonates include alstonite and barytocalcite [both polymorphs of $\left.\mathrm{CaBa}\left(\mathrm{CO}_{3}\right)_{2}\right]$, norsethite $\left[\mathrm{BaMg}\left(\mathrm{CO}_{3}\right)_{2}\right]$, and the rare earth carbonates burbankite $\left[(\mathrm{Na}, \mathrm{Ca})_{3}(\mathrm{Sr}, \mathrm{Ba}, \mathrm{Ce})_{3}\left(\mathrm{CO}_{3}\right)_{5}\right]$, sahamalite-(Ce) $\left[\mathrm{Ce}_{2} \mathrm{Mg}\left(\mathrm{CO}_{3}\right)_{4}\right]$ and carbocernaite $\left[(\mathrm{Ca}, \mathrm{Na})(\mathrm{Sr}, \mathrm{Ce}, \mathrm{La})\left(\mathrm{CO}_{3}\right)_{2}\right]$. Note that reference is sometimes made to "breunnerite" $\left[(\mathrm{Mg}, \mathrm{Fe}) \mathrm{CO}_{3}\right]$, but this Fe-rich magnesite is not a valid mineral species.

The alkali carbonatites are exemplified by Oldoinyo Lengai in Tanzania (the only currently active carbonatite volcano), and feature several minerals with the general formula $\left[(\mathrm{Na}, \mathrm{K})_{2} \mathrm{Ca}\left(\mathrm{CO}_{3}\right)_{2}\right]$ (Dawson 1962, 1966; Chang et al. 1997). The two sodium-rich end-members are nyerereite (typically with $\mathrm{Na} / \mathrm{K} \sim 4.5$, though the official IMA chemical formula lacks $\mathrm{K}$ ) and a possible higher-temperature polymorph zemkorite (with $\mathrm{Na} / \mathrm{K} \sim 6.2$; again, the official IMA-approved formula lacks K); potassium end-member species are fairchildite and a lowertemperature form, bütschliite (Dawson 1962; Mrose et al. 1966; McKie and Frankis 1977; Yergorov et al. 1988; Chang et al. 1997). These phases are also accompanied by the rare sodium carbonate gregoryite $\left[\mathrm{Na}_{2}\left(\mathrm{CO}_{3}\right)\right]$, which can only form in alkali-rich, alkaline earth-poor systems.

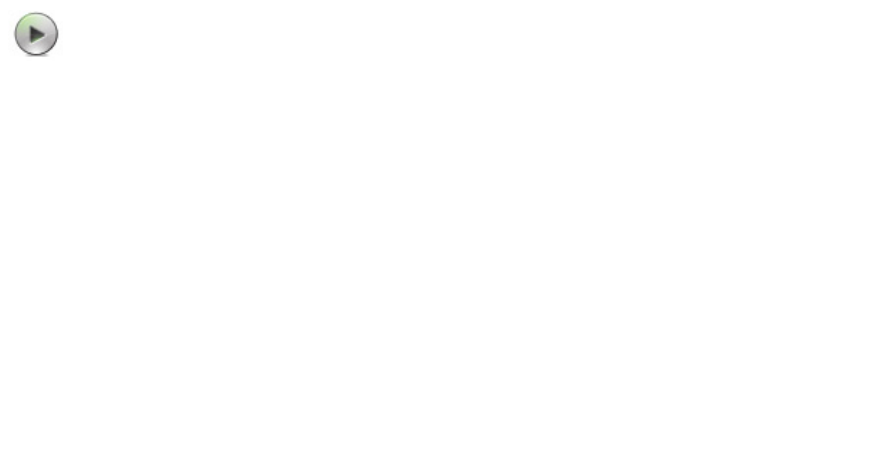

Figure 14. The structure of huntite $\left[\mathrm{CaMg}_{3}\left(\mathrm{CO}_{3}\right)_{4}\right]$. (hexagonal; space group $R 32 ; a=9.503 \AA, c=$ $7.821 \AA ; Z=3$ ). The huntite structure is unusual in the trigonal prism coordination of calcium, coupled with octahedral coordination of magnesium. [Animation 10: For readers of the electronic version, click the image for an animation of the huntite crystal structure.]
Carbonatites can also develop suites of rare earth element (REE) carbonate or carbonatefluoride minerals, including the bastnäsite group $\left[\operatorname{REE}\left(\mathrm{CO}_{3}\right) \mathrm{F}\right.$, found with dominant REE $=\mathrm{Ce}, \mathrm{La}, \mathrm{Nd}$, or $\mathrm{Y}]$, synchysite and parasite [both $\mathrm{CaREE}\left(\mathrm{CO}_{3}\right)_{2} \mathrm{~F}$, found with dominant $\mathrm{REE}=\mathrm{Ce}, \mathrm{Nd}$, or $\mathrm{Y}]]$, huanghoite- $(\mathrm{Ce})\left[\mathrm{Ba}(\mathrm{Ce}, \mathrm{REE})\left(\mathrm{CO}_{3}\right)_{2} \mathrm{~F}\right]$, and the cordylite group $\left[\mathrm{NaBaREE}_{2}\left(\mathrm{CO}_{3}\right)_{4} \mathrm{~F}\right.$, found with dominant $\mathrm{REE}=\mathrm{Ce}$ or La]. REE-carbonatites are often geologically associated with $\mathrm{U}$ and Th minerals (Ruberti et al 2008; also see section on "Uranyl carbonates" below). Two of the world's largest economic ore bodies for REE are carbonatites: Mountain Pass California (age 1.37 Ga; Olson et al. 1954; Jones and Wyllie 1986; Castor 2008) and Bayan Obo, China (age 1.35 Ga: Le Bas et al. 1992; Yang et al. 2011). Finally, several hydrous carbonates, including the uncommon REE phases of the ancylite group $\left[(\mathrm{Ca}, \mathrm{Sr}, \mathrm{Pb})(\mathrm{REE})\left(\mathrm{CO}_{3}\right)_{2}(\mathrm{OH}) \cdot \mathrm{H}_{2} \mathrm{O}\right.$, found with dominant $\mathrm{REE}=\mathrm{Ce}, \mathrm{La}$, or $\mathrm{Nd}]$, calkinsite- $(\mathrm{Ce})\left[(\mathrm{Ce}, \mathrm{REE})_{2}\left(\mathrm{CO}_{3}\right)_{2} \cdot 4 \mathrm{H}_{2} \mathrm{O}\right]$, and the lanthanite group $\left[\mathrm{REE}_{2}\left(\mathrm{CO}_{3}\right)_{3} \cdot 8 \mathrm{H}_{2} \mathrm{O}\right.$, found with dominant $\mathrm{REE}=\mathrm{Ce}, \mathrm{La}$, or $\mathrm{Nd}$ ], along with two closely associated hydrated $\mathrm{Mg}-\mathrm{Al}$ carbonates, manasseite $\left[\mathrm{Mg}_{6} \mathrm{Al}_{2}\left(\mathrm{CO}_{3}\right)(\mathrm{OH})_{16} \cdot 4 \mathrm{H}_{2} \mathrm{O}\right]$ and hydrotalcite $\left[\mathrm{Mg}_{6} \mathrm{Al}_{2}\left(\mathrm{CO}_{3}\right)\right.$ $(\mathrm{OH})_{16} \cdot 4 \mathrm{H}_{2} \mathrm{O}$ ], have been reported from some carbonatites (Kapustin 1980).

\section{Hydrous carbonates}

Most carbon-bearing minerals-more than 210 of the approximately 320 IMA approved carbonate species-are hydrated or hydrous (Table 6; http://rruff.info/ima/). These diverse species, whose classification has been systematized by Mills et al. (2009), occupy numerous specialized near-surface niches but are for the most part volumetrically minor. Most of these diverse minerals have mixed anionic groups, including more than 30 carbonate-sulfates, more than 40 carbonate-silicates, and more than 20 carbonate-phosphates, plus carbonates with uranyl, arsenate, borate, and other ionic groups, which represent near-surface alteration products of other minerals (see Tables 5 and 6 for some of the more common representative examples).

Malachite and azurite. The common hydrous copper carbonates, malachite $\left[\mathrm{Cu}_{2}(\mathrm{OH})_{2} \mathrm{CO}_{3}\right]$ and azurite $\left[\mathrm{Cu}_{3}(\mathrm{OH})_{2}\left(\mathrm{CO}_{3}\right)_{2}\right]$, which form in the oxidized zone of copper deposits, are typical of a large number of near-surface carbonate phases, including more than 20 other hydrous copper carbonates. These colorful minerals are among the thousands of mineral species that Hazen et al. (2008) identified as potentially biologically mediated (Hazen et al. 2013).

Uranyl carbonates. At least 30 carbonates incorporate the $\left(\mathrm{UO}_{2}\right)^{2+}$ uranyl cation group. These fascinating and colorful phases, which commonly form as alteration products of nearsurface uranium ore bodies, include 4 anhydrous carbonates: rutherfordine $\left[\left(\mathrm{UO}_{2}\right)\left(\mathrm{CO}_{3}\right)\right]$, the isomorphous alkali uranyl carbonates agricolite and čejkaite $\left[\mathrm{K}_{4}\left(\mathrm{UO}_{2}\right)\left(\mathrm{CO}_{3}\right)_{3}\right.$ and $\mathrm{Na}_{4}\left(\mathrm{UO}_{2}\right)$ $\left(\mathrm{CO}_{3}\right)_{3}$, respectively], and widenmannite $\left[\mathrm{Pb}_{2}\left(\mathrm{UO}_{2}\right)\left(\mathrm{CO}_{3}\right)_{3}\right]$. Most of the hydrous and hydrated uranyl carbonates are rare; 20 of these species are documented from five or fewer localities (http://MinDat.org), while only four of these hydrated uranium carbonate species are known from more than 30 localities: andersonite $\left[\mathrm{Na}_{2} \mathrm{Ca}\left(\mathrm{UO}_{2}\right)\left(\mathrm{CO}_{3}\right)_{3} \cdot 6 \mathrm{H}_{2} \mathrm{O}\right]$, bayleyite $\left[\mathrm{Mg}_{2}\left(\mathrm{UO}_{2}\right)\right.$ $\left.\left(\mathrm{CO}_{3}\right)_{3}\left(\mathrm{H}_{2} \mathrm{O}\right)_{12} \cdot 6 \mathrm{H}_{2} \mathrm{O}\right]$, liebigite $\left[\mathrm{Ca}_{2}\left(\mathrm{UO}_{2}\right)\left(\mathrm{CO}_{3}\right)_{3} \cdot 11 \mathrm{H}_{2} \mathrm{O}\right]$, and schrockingerite $\left[\mathrm{NaCa}_{3}\left(\mathrm{UO}_{2}\right)\right.$ $\left.\left(\mathrm{SO}_{4}\right)\left(\mathrm{CO}_{3}\right)_{3} \mathrm{~F} \cdot 10 \mathrm{H}_{2} \mathrm{O}\right]$. These minerals are all $\mathrm{Ca}$ or $\mathrm{Mg}$ carbonates that presumably formed by alteration of calcite or dolomite in a relatively oxidized subsurface environment-conditions that must significantly postdate the Great Oxidation Event (Hazen et al. 2008, 2009; Sverjensky and Lee 2010; Hazen et al. 2013).

Hydrated calcium carbonates. In addition to the mineralogically complex hydrated carbonates outlined above, hydrated phases of calcium carbonate-i.e., ikaite $\left[\mathrm{CaCO}_{3} \cdot 6 \mathrm{H}_{2} \mathrm{O}\right]$ and its pseudomorphs [which have been given a number of unofficial varietal names such as thinolite, glendonite, jarrowite, and fundylite (Browell 1860; Dana 1884; Shearman and Smith 1985; Ito 1996; Swainson and Hammond 2001)], plus monohydrocalcite $\left(\mathrm{CaCO}_{3} \cdot \mathrm{H}_{2} \mathrm{O}\right)$ and hydromagnesite $\left[\mathrm{Mg}_{5}\left(\mathrm{CO}_{3}\right)_{4}(\mathrm{OH})_{2} \cdot 4 \mathrm{H}_{2} \mathrm{O}\right]$ - play critical roles in the near-surface co-evolution of the geosphere and biosphere. Hydrated calcite is common in modern microbial systems 
and commonly represents an initial precipitate phase within microbially mediated carbonate deposits. Similarly, pseudomorphs after ikaite provide thermodynamic indicators of cold marine temperatures, and can potentially be used as a unique indicator of glaciated conditions in the geologic past, for example, as pseudomorphs after ikaite in the Mississippian of Alberta, Canada (Brandley and Krause 1997) and in glendonites in Neoproterozoic shallow shelf environments (James et al. 1998).

\section{Minerals incorporating organic molecules}

The IMA has recognized approximately 50 organic minerals, and it is likely that many more species remain to be identified and described (Table 7; http://rruff.info/ima). These diverse phases fall into three main categories — organic molecular crystals, minerals with organic molecular anions, and clathrates. Note that while many of these minerals are a direct or indirect consequence of biological activity, some minerals with organic molecules may have a nonbiological origin. Consequently, Perry et al. (2007) have also introduced the term "organomineral" to designate "mineral products containing organic carbon," but "not directly produced by living cells." As examples they cite carbon-bearing siliceous hot-spring deposits, desert varnish, stromatolites, and a variety of trace fossils.

Organic molecular crystals. Organic molecular crystals encompass those carbon-bearing minerals in which electrically neutral organic molecules crystalize into a periodic arrangement, principally through van der Waals interactions (Table 7). This diverse group includes a number of species known only as accessory minerals associated with coal; for example, 9 different hydrocarbon minerals, such as kratochvilite $\left(\mathrm{C}_{13} \mathrm{H}_{10}\right)$, fichtelite $\left(\mathrm{C}_{19} \mathrm{H}_{34}\right)$, dinite $\left(\mathrm{C}_{20} \mathrm{H}_{36}\right)$, and evenkite $\left(\mathrm{C}_{24} \mathrm{H}_{48}\right)$; acetamide $\left(\mathrm{CH}_{3} \mathrm{CONH}_{2}\right)$; and the ring-shaped nickel porphyrin mineral abelsonite, $\mathrm{Ni}\left(\mathrm{C}_{31} \mathrm{H}_{32} \mathrm{~N}_{4}\right)$. Burning coal mines also produce molecular crystals through sublimation, including kladnoite $\left[\mathrm{C}_{6} \mathrm{H}_{4}(\mathrm{CO})_{2} \mathrm{NH}\right]$ and hoelite $\left(\mathrm{C}_{14} \mathrm{H}_{8} \mathrm{O}_{2}\right.$; Jehlička et al. 2007). Other molecular crystals are unique to fossilized wood [flagstaffite $\left(\mathrm{C}_{10} \mathrm{H}_{22} \mathrm{O}_{3}\right)$ ]; roots [refikite $\left(\mathrm{C}_{20} \mathrm{H}_{32} \mathrm{O}_{2}\right)$ ]; or bat guano deposits in caves, for example the purines uricite $\left(\mathrm{C}_{5} \mathrm{H}_{4} \mathrm{~N}_{4} \mathrm{O}_{3}\right)$ and guanine $\left(\mathrm{C}_{5} \mathrm{H}_{5} \mathrm{~N}_{5} \mathrm{O}\right)$, and urea $\left[\mathrm{CO}\left(\mathrm{NH}_{2}\right)_{2}\right]$. It is intriguing to note that average temperatures on Earth are too high for many crystals of small organic molecules to form, including crystalline forms of carbon dioxide (which has been observed near the poles of Mars; Byrne and Ingersoll 2003), methane, ethane $\left(\mathrm{C}_{2} \mathrm{H}_{6}\right)$, ethylene $\left(\mathrm{C}_{2} \mathrm{H}_{2}\right)$, and propane $\left(\mathrm{C}_{3} \mathrm{H}_{8}\right)$. One can anticipate that these and many other such minerals await discovery in the cold, hydrocarbon-rich near-surface environment of Saturn's moon Titan, as well as in the form of condensed phases in dense molecular clouds (Glein 2012).

Minerals with organic anions. Approximately 25 mineral species incorporate organic anions bonded to $\mathrm{Ca}, \mathrm{Mg}, \mathrm{Cu}, \mathrm{Na}$, and other metal cations (Table 7). Predominant among these organic salt minerals are more than a dozen oxalates with the $\left(\mathrm{C}_{2} \mathrm{O}_{4}\right)^{2-}$ anion. The most common oxalate is weddellite $\left[\mathrm{Ca}\left(\mathrm{C}_{2} \mathrm{O}_{4}\right) \cdot 2 \mathrm{H}_{2} \mathrm{O}\right]$, which is found in such varied environments as bat guano, sediments derived from lichens, human kidney stones, cactus (saguaro, Carnegiea gigantea), and the depths of the Weddell Sea. Other oxalates include caoxite $\left[\mathrm{Ca}\left(\mathrm{C}_{2} \mathrm{O}_{4}\right) 3 \mathrm{H}_{2} \mathrm{O}\right]$, glushinskite $\left[\mathrm{Mg}\left(\mathrm{C}_{2} \mathrm{O}_{4}\right) \cdot 2 \mathrm{H}_{2} \mathrm{O}\right]$, humboldtine $\left[\mathrm{Fe}\left(\mathrm{C}_{2} \mathrm{O}_{4}\right) \cdot 2 \mathrm{H}_{2} \mathrm{O}\right]$, lindbergite $\left[\mathrm{Mn}\left(\mathrm{C}_{2} \mathrm{O}_{4}\right) \cdot 2 \mathrm{H}_{2} \mathrm{O}\right]$, natroxalate $\left[\mathrm{Na}_{2}\left(\mathrm{C}_{2} \mathrm{O}_{4}\right)\right]$, and oxammite $\left[\left(\mathrm{NH}_{4}\right)_{2}\left(\mathrm{C}_{2} \mathrm{O}_{4}\right) \cdot \mathrm{H}_{2} \mathrm{O}\right]$ (the latter a biomineral known exclusively from guano deposits).

Other organic anions in minerals include formate $(\mathrm{HCOO})^{-1}$, for example in formicate $\left[\mathrm{Ca}(\mathrm{CHOO})_{2}\right]$ and dashkovite $\left[\mathrm{Mg}(\mathrm{HCOO})_{2} \cdot 2 \mathrm{H}_{2} \mathrm{O}\right]$; acetyl $\left(\mathrm{CH}_{3} \mathrm{COO}\right)^{-1}$ in hoganite $\left[\mathrm{Cu}\left(\mathrm{CH}_{3} \mathrm{COO}\right)_{2} \cdot \mathrm{H}_{2} \mathrm{O}\right]$ and calclacite $\left[\mathrm{Ca}\left(\mathrm{CH}_{3} \mathrm{COO}\right) \mathrm{Cl} \cdot 5 \mathrm{H}_{2} \mathrm{O}\right]$ (the latter mineral known only from specimens of limestone stored in wooden drawers); methyl sulfonate $\left(\mathrm{CH}_{3} \mathrm{SO}_{3}\right)^{-1}$ in ernstburkite $\left[\mathrm{Mg}\left(\mathrm{CH}_{3} \mathrm{SO}_{3}\right)_{2} \cdot 12 \mathrm{H}_{2} \mathrm{O}\right]$; and thiocyanate $(\mathrm{SCN})^{-1}$ in julienite $\left[\mathrm{Na}_{2} \mathrm{Co}(\mathrm{SCN})_{4} \cdot 8 \mathrm{H}_{2} \mathrm{O}\right]$. Finally, Rastsvetaeva et al. (1996) describe a $\mathrm{Cu}^{2+}$ succinate monohydrate phase that occurs as a consequence of washing copper mineral specimens with detergents.
Table 7. Representative minerals incorporating organic molecules.

\begin{tabular}{|c|c|}
\hline Name & Formula \\
\hline \multicolumn{2}{|c|}{ Molecular Crystals: Hydrocarbons } \\
\hline Kratochvilite & $\mathrm{C}_{13} \mathrm{H}_{10}$ \\
\hline Fichtelite & $\mathrm{C}_{19} \mathrm{H}_{34}$ \\
\hline Dinite & $\mathrm{C}_{20} \mathrm{H}_{36}$ \\
\hline Evenkite & $\mathrm{C}_{24} \mathrm{H}_{48}$ \\
\hline \multicolumn{2}{|c|}{ Other Organic Molecular Crystals } \\
\hline Acetamide & $\mathrm{CH}_{3} \mathrm{CONH}_{2}$ \\
\hline Abelsonite & $\mathrm{Ni}\left(\mathrm{C}_{31} \mathrm{H}_{32} \mathrm{~N}_{4}\right)$ \\
\hline Kladnoite & $\mathrm{C}_{6} \mathrm{H}_{4}(\mathrm{CO})_{2} \mathrm{NH}$ \\
\hline Hoelite & $\mathrm{C}_{14} \mathrm{H}_{8} \mathrm{O}_{2}$ \\
\hline Flagstaffite & $\left.\mathrm{C}_{10} \mathrm{H}_{22} \mathrm{O}_{3}\right)$ \\
\hline Refikite & $\mathrm{C}_{20} \mathrm{H}_{32} \mathrm{O}_{2}$ ) \\
\hline Uricite & $\mathrm{C}_{5} \mathrm{H}_{4} \mathrm{~N}_{4} \mathrm{O}_{3}$ \\
\hline Guanine & $\mathrm{C}_{5} \mathrm{H}_{5} \mathrm{~N}_{5} \mathrm{O}$ \\
\hline Urea & $\mathrm{CO}\left(\mathrm{NH}_{2}\right)_{2}$ \\
\hline \multicolumn{2}{|c|}{ Minerals with Organic Anions: Oxalates } \\
\hline Weddellite & $\mathrm{Ca}\left(\mathrm{C}_{2} \mathrm{O}_{4}\right) \cdot 2 \mathrm{H}_{2} \mathrm{O}$ \\
\hline Caoxite & $\mathrm{Ca}\left(\mathrm{C}_{2} \mathrm{O}_{4}\right) \cdot 3 \mathrm{H}_{2} \mathrm{O}$ \\
\hline Glushinskite & $\mathrm{Mg}\left(\mathrm{C}_{2} \mathrm{O}_{4}\right) \cdot 2 \mathrm{H}_{2} \mathrm{O}$ \\
\hline Humboldtine & $\mathrm{Fe}\left(\mathrm{C}_{2} \mathrm{O}_{4}\right) \cdot 2 \mathrm{H}_{2} \mathrm{O}$ \\
\hline Lindbergite & $\mathrm{Mn}\left(\mathrm{C}_{2} \mathrm{O}_{4}\right) \cdot 2 \mathrm{H}_{2} \mathrm{O}$ \\
\hline Natroxalate & $\mathrm{Na}_{2}\left(\mathrm{C}_{2} \mathrm{O}_{4}\right)$ \\
\hline Oxammite & $\left(\mathrm{NH}_{4}\right)_{2}\left(\mathrm{C}_{2} \mathrm{O}_{4}\right) \cdot \mathrm{H}_{2} \mathrm{O}$ \\
\hline \multicolumn{2}{|c|}{ Other Minerals with Organic Anions } \\
\hline Formicate & $\mathrm{Ca}(\mathrm{CHOO})_{2}$ \\
\hline Dashkovaite & $\mathrm{Mg}(\mathrm{HCOO})_{2} \cdot 2 \mathrm{H}_{2} \mathrm{O}$ \\
\hline Hoganite & $\mathrm{Cu}\left(\mathrm{CH}_{3} \mathrm{COO}\right)_{2} \cdot \mathrm{H}_{2} \mathrm{O}$ \\
\hline Calclacite & $\mathrm{Ca}\left(\mathrm{CH}_{3} \mathrm{COO}\right) \mathrm{Cl} \cdot 5 \mathrm{H}_{2} \mathrm{O}$ \\
\hline Ernstburkite & $\mathrm{Mg}\left(\mathrm{CH}_{3} \mathrm{SO}_{3}\right)_{2} \cdot 12 \mathrm{H}_{2} \mathrm{O}$ \\
\hline Julienite & $\mathrm{Na}_{2} \mathrm{Co}(\mathrm{SCN})_{4} \cdot 8 \mathrm{H}_{2} \mathrm{O}$ \\
\hline \multicolumn{2}{|l|}{ Clathrates } \\
\hline Chibaite & $\mathrm{SiO}_{2} \cdot n\left(\mathrm{CH}_{4}, \mathrm{C}_{2} \mathrm{H}_{6}, \mathrm{C}_{3} \mathrm{H}_{8}, \mathrm{C}_{4} \mathrm{H}_{10}\right) ;\left(n_{\max }=3 / 17\right)$ \\
\hline Melanophlogite & $\mathrm{SiO}_{2}$ \\
\hline Methane hydrate* & $\mathrm{H}_{2} \mathrm{O}\left[\mathrm{CH}_{4}\right]$ \\
\hline
\end{tabular}

Clathrate silicates. Clathrates comprise a third as yet poorly described group of minerals containing organic molecules. These minerals feature open three-dimensional framework structures that incorporate molecules in cage-like cavities. Chibaite and melanophlogite are silica clathrates with open zeolite-like $\mathrm{SiO}_{2}$ frameworks that may contain hydrocarbons from methane to butane $\left(\mathrm{C}_{4} \mathrm{H}_{10}\right)$ as the guest molecule (Skinner and Appleman 1963; Momma et al. 2011). Melanophlogite with $\mathrm{CO}_{2}$ and/or methane as the guest molecule has been found in natrocarbonatite lavas at Oldoinyo Lengai (Carmody 2012).

Clathrate hydrates. Water-based clathrates, also known as gas hydrates or clathrate hydrates, are remarkable crystalline compounds that form at low temperatures (typically $<0$ ${ }^{\circ} \mathrm{C}$ ) and elevated pressures ( $>6 \mathrm{MPa}$ ). These materials have attracted considerable attention because of their potential for applications to energy storage and recovery applications (Max 
2003; Boswell 2009; Koh et al. 2009, 2011). Different gas clathrate hydrate structure types have a variety of cage sizes and shapes, which depend primarily on the size and character of the gas molecule.

The principal documented natural clathrate hydrate mineral is an as yet unnamed methane hydrate commonly known as "methane ice, which crystallizes in marine sediments of the continental shelves or in permafrost zones below a depth of 130 (Hyndman and Davis 1992). Methane hydrate is structurally similar to the silica clathrates. Its cubic structure (space group Pm3m, $a=12 \AA$ ) features a three-dimensional $\mathrm{H}_{2} \mathrm{O}$ framework with two types of cages partially filled with $\mathrm{CH}_{4}$ molecules: a pentagonal dodecahedron (designated $5^{12}$, or a cage formed by 12 interconnected 5-member rings of $\mathrm{H}_{2} \mathrm{O}$ ) and a tetrakaidecahedron (designated $5^{12} 6^{2}$ ), each with average radii $\sim 4 \AA$, each holding one $\mathrm{CH}_{4}$ molecule (Fig. 15; Animation 11). Although the methane content is variable, methane ice holds on average $\sim 0.17$ mole of methane per mole of water, corresponding to a density of $\sim 0.9 \mathrm{~g} / \mathrm{cm}^{3}$ (Max 2003).

The geographic distribution of methane hydrate is extensive, with hundreds of confirmed deposits (Hyndman and Spence 1992; Kvenvolden 1995; Milkov 2004). The total methane storage in clathrates was estimated by Allison and Boswell (2007) as $2 \times 10^{16} \mathrm{~m}^{3}$-a quantity orders of magnitude greater than that represented by all other natural gas reserves. Annual natural gas consumption in North America, by comparison, is $\sim 6 \times 10^{11} \mathrm{~m}^{3}$ (Boswell 2009). In fact, the methane stored in clathrate hydrates may exceed the energy represented by known reserves of all other fossil fuels combined (Kvenvolden 1995; Grace et al. 2008).

In addition to this common phase, Guggenheim and Koster van Groos (2003) and Koster van Groos and Guggenheim (2009) have reported the synthesis of a possible new gas-hydrate phase that consists of a clay-methane hydrate intercalate. In addition, Chou et al. (2000) have reported other methane clathrate hydrate phases that occur exclusively at high pressures.

\section{Mineral-molecule interactions}

Finally, it should be noted that organic molecules often interact strongly with mineral surfaces, especially in aqueous environments (Hazen 2006; Jonsson et al. 2009; Bahri et al. 2011; Cleaves et al. 2011). Such interactions of organic species with mineral surfaces have received special attention for at least two reasons related to the biosphere. First, a number of
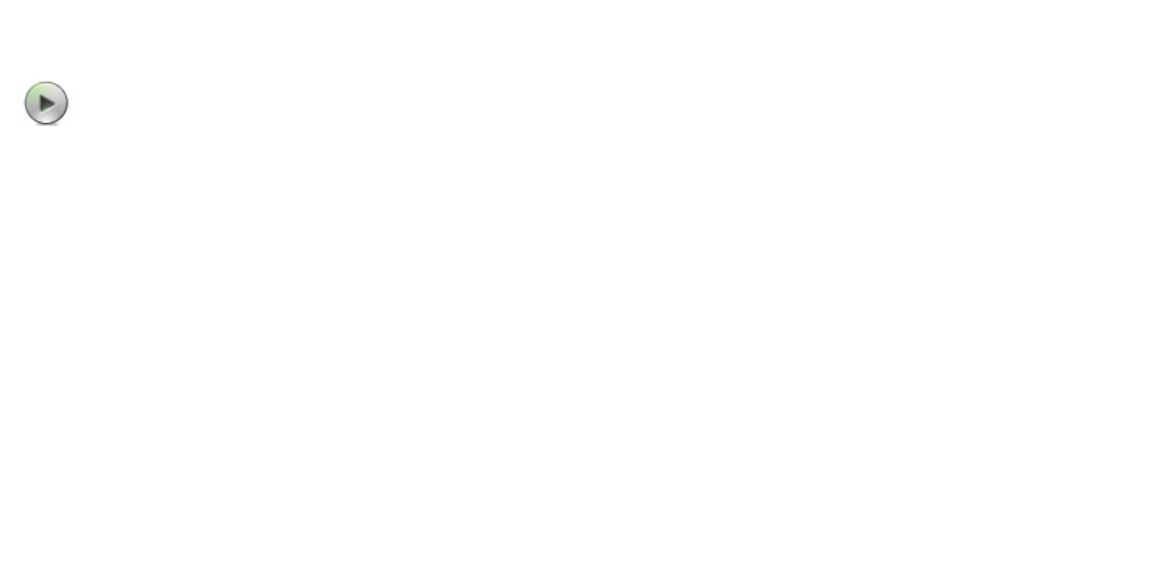

Figure 15. Methane hydrate. (a) The structure of methane hydrate $\left[\mathrm{H}_{2} \mathrm{O} \cdot \mathrm{CH}_{4}\right]$ (cubic; space group $\mathrm{Pm} 3 m$; $a=12 \AA$ ). (b) Methane hydrate burns at room conditions, as the hydrate melts and methane is released. Photo courtesy of Jan Steffan, Expedition SO148, GEOMAR. [Animation 11: For readers of the electronic version, click the image for an animation of the methane hydrate crystal structure.] minerals have been invoked as possibly playing key roles in the origins of life through the selection, concentration, protection, and templating of biomolecules, as well as the possible catalysis of biomolecules (Bernal 1951; Goldschmidt 1952; Orgel 1998; Lahav 1999; Schoonen et al. 2004; Hazen 2005, 2006). Specific hypotheses focus on the roles of hydroxides (Holm et al. 1993; Pitsch et al. 1995; Hill et al. 1998), quartz (Bonner et al. 1974, 1975; Evgenii and Wolfram 2000), feldspars and zeolites (Smith 1998; Parsons et al. 1998; Smith et al. 1999), carbonates (Hazen et al. 2001), phosphates (Weber 1982, 1995; Acevedo and Orgel 1986), borates (Ricardo et al. 2004; Grew et al. 2011), phosphides (Pasek et al. 2007), and sulfides (Wächtershäuser 1988, 1990, 1993; Russell et al. 1994; Russell and Hall 1997; Huber and Wächtershäuser 1998; Bebié and Schoonen 2000; Cody et al. 2000, 2001, 2004; Cody 2004). In this regard, clay minerals have received special attention for their potential ability to template and catalyze the polymerization of amino acids and nucleotides as steps in the origins of life (Cairns-Smith 1982, 2005; Cairns-Smith and Hartman 1986; Ferris et al. 1996; Ertem and Ferris 1996; Orgel 1998; Ferris 2005).

A second possible influence of mineral-molecule interactions on the biosphere also invokes clay minerals, which might have contributed significantly to the rise of atmospheric oxygen through the adsorption, concentration, and subsequent burial of significant amounts of organic matter from the terrestrial environment (Kennedy et al. 2006). This process of organic burial is one of the most efficient mechanisms for atmospheric oxidation (Berner et al 2000; Hayes and Waldbauer 2006; Hazen et al. 2013).

\section{CONCLUSIONS: UNRESOLVED QUESTIONS IN CARBON MINERALOGY}

More than two centuries of mineralogical research have revealed much regarding the varied C-bearing mineral phases in Earth's near-surface environment. Nevertheless, much remains to be learned. Among the most fundamental mineralogical questions-one evident from any museum display of carbonate minerals-is what physical, chemical, and biological processes lead to the remarkable range of calcite crystal forms? No other crystalline phase exhibits such a wide range of morphologies. What environmental factors influence calcite crystal forms? And why don't other rhombohedral carbonates display a similar variety?

Studies of minerals that incorporate organic molecules are in their infancy, and numerous other phases at the interface between the crystalline and biological worlds are likely awaiting discovery. Characterization of such phases may prove especially important in resolving debates regarding abiotic versus biotic origins of some deep organic molecules (Sephton and Hazen 2013; McCollom 2013). Furthermore, organic mineralogy may play a dominant role on Titan, as well as planets and moons in other C-rich star systems. Indeed, carbon mineralogy may provide one of the most sensitive geological indicators of the evolution and present state of other worlds.

\section{ACKNOWLEDGMENTS}

We thank John Armstrong, Russell Hemley, Andrea Mangum, Craig Schiffries, and Dimitri Sverjensky for invaluable discussions and suggestions during the preparation of this manuscript. We thank Lauren Cryan, Shaun Hardy, and Merri Wolf, who provided critical technical support. The authors gratefully acknowledge support from the Deep Carbon Observatory, the Alfred P. Sloan Foundation, the Carnegie Institution of Washington, the National Science Foundation, and NASA's Astrobiology Institute for support of this study. 


\section{REFERENCES}

Acevedo OL, Orgel LE (1986) Template-directed oligonucleotide ligation on hydroxylapatite. Nature 321:790792

Acheson G (1893) U.S. Patent 492,767. Production of Artificial Crystalline Carbonaceous Material

Addadi L, Raz S, Weiner S (2003) Taking advantage of disorder: amorphous calcium carbonate and its roles in biomineralization. Adv Mater 15:959-970

Adler HH, Kerr PE (1963) Infrared absorption frequency trends for anhydrous normal carbonates. Am Mineral 48:124-137

Alexander CMO'D (1990) In situ measurement of interstellar silicon carbide in two CM chondrite meteorites. Nature 348:715-717, doi:10.1038/348715a0

Alexander CMO'D (1993) Presolar SiC in chondrites: how variable and how many sources? Geochim Cosmochim Acta 57:2869-2888

Allison E, Boswell R (2007) Methane hydrate, future energy within our grasp, an overview. DOE Overview Document, http://www.fossil.energy. gov/programs/oilgas/hydrates/

Anderson RE, Brazelton WJ, Baross JA (2013) The deep viriosphere: assessing the viral impact on microbial community dynamics in the deep subsurface. Rev Mineral Geochem 75:649-675

Angus JC, Hayman CC (1988) Low-pressure metastable growth of diamond and diamondlike phases. Science 241:913-921

Angus JC, Will HA, Stanko WS (1968) Growth of diamond seed crystals by vapor deposition. J Appl Phys 39:2915-2922

Bahri S, Jonsson CM, Jonsson CL, Azzolini D, Sverjensky DA, Hazen RM (2011) Adsorption and surface complexation study of L-DOPA on rutile $\left(\mathrm{TiO}_{2}\right)$ in $\mathrm{NaCl}$ solutions. Environ Sci Technol 45:3959-3966

Bartley JK, Kah LC (2004) Marine carbon reservoir, $\mathrm{C}_{\mathrm{org}}-\mathrm{C}_{\text {carb }}$ coupling, and the evolution of the Proterozoic carbon cycle. Geology 32:129-132

Bathurst RGC (1976) Carbonate Sediments and their Diagenesis (Developments in Sedimentology 12). Elsevier, New York

Beard J (1988) Explosive mixtures. New Scientist 5 November 1988:43-47

Bebié J, Schoonen MAA (2000) Pyrite surface interaction with selected organic aqueous species under anoxic conditions. Geochem Trans 1:47, doi: 10.1186/1467-4866-1-47

Bell K (ed) (1989) Carbonatites: Genesis and Evolution. Unwin Hyman, London

Belluci S (2005) Carbon nanotubes: physics and applications. Phys Status Solidi C 2:34-47

Bergman SC (1987) Lamproites and other potassium-rich igneous rocks: a review of their occurrences, mineralogy, and geochemistry. In: Alkaline Igneous Rocks. Fitton JG, Upton BJG (eds) Geol Soc London Spec Publ 30:103-119

Bernal JD (1924) The structure of graphite. Proc R Soc London A 106:749-777
Bernal JD (1951) The Physical Basis of Life. Routledge and Kegan Paul, London

Berner EK, Berner RA (2012) Global Environment: Water, Air and Geochemical Cycles. Princeton University Press, Princeton, New Jersey

Berner RA (2004) The Phanerozoic Carbon Cycle. Oxford University Press, Oxford, UK
Berner RA, Petsch SA, Lake JA, Beerling DJ, Popp BN, Lane RS, Laws EA, Westley MB, Cassar N, Woodward FI, Quick WP (2000) Isotope fractionation and atmospheric oxygen: implications for Phanerozoic $\mathrm{O}_{2}$ evolution. Science 287:1630-1633

Bhatnagar M, Baliga BJ (1993) Comparison of $6 \mathrm{H}-\mathrm{SiC}, 3 \mathrm{C}-\mathrm{SiC}$, and $\mathrm{Si}$ for power devices. IEEE Trans Electron Devices 40:645-655, doi:10.1109/16.199372

Bird JM, Weathers MS (1977) Native iron occurrences of Disko Island, Greenland. J Geol 85:359-371

Bonner WA, Kavasmaneck PR, Martin FS, Flores JJ (1974) Asymmetric adsorption of alanine by quartz. Science 186:143-144

Bonner WA, Kavasmaneck PR, Martin FS, Flores JJ (1975) Asymmetric adsorption by quartz: a model for the prebiotic origin of optical activity. Origins Life 6:367-376

Boswell R (2009) Is gas hydrate energy within reach? Science 325:957-958, doi: 10.1126/science.1175074 Bragg WH, Bragg WL (1913) The structure of diamond. Proc Roy Soc London A 89:277-291

Bragg WL (1914) The analysis of crystals by the x-ray spectrometer. Proc Roy Soc London A 89:468-489

Bragg WL (1924) The structure of aragonite. Proc Royal Soc London A 105:16-39

Bragg WL, Claringbull GF, Taylor WH (1965) Crystal Structures of Minerals. Cornell University Press, Ithaca, New York

Brandley RT, Krause FF (1997) Upwelling, thermoclines and wave-sweeping on an equatorial carbonate ramp. SEPM Spec Pub 56:365-390

Brett R (1967) Cohenite: its occurrence and a proposed origin. Geochim Cosmochim Acta 31:143-159

Bridgman PW (1931) The Physics of High Pressure. MacMillan, New York

Bridgman PW (1946) An experimental contribution to the problem of diamond synthesis. J Chem Phys 15:92-
Brooks CR (1996). Principles of the Heat Treatment of Plain Carbon and Low Alloy Steels. ASM International, Materials Park, Ohio

Browell EJJ (1860) Description and analysis of an undescribed mineral from Jarrow Slake. Tyneside Naturalists Field Club 5:103-104

Bundy FP (1967) Hexagonal diamond-a new form of carbon. J Chem Phys 46:3437-3446, doi: $10.1063 / 1.1841236$

Bundy FP, Bovenkerk HP, Strong HM, Wentorf RH Jr. (1961) Diamond-graphite equilibrium line from growth and graphitization of diamond. J Chem Phys 35:383-391

Bundy FP, Hall HT, Strong HM, Wentorf RH Jr (1955) Man-made diamonds. Nature 176:51-55

Byrne S, Ingersoll AP (2003) A sublimation model for Martian south polar ice features. Science 299:10511053, doi: $10.1126 /$ science. 1080148

Cairns-Smith AG (1982) Genetic Takeover and the Mineral Origins of Life. Cambridge University Press, Cambridge, UK

Cairns-Smith AG (2005) Sketches for a mineral genetic system. Elements 1:157-161

Cairns-Smith AG, Hartman H (1986) Clay Minerals and the Origin of Life. Cambridge University Press, Cambridge, UK

Capitani GC, Di Pierro S, Tempesta G (2007) The 6H-SiC structure model: further refinement from SCXRD data from a terrestrial moissanite. Am Mineral 92:403-407

Carlson WD (1983) The polymorphs of $\mathrm{CaCO}_{3}$ and the aragonite-calcite transformation. Rev Mineral 11:191225

Carmody, L. (2012) Geochemical characteristics of carbonatite-related volcanism and sub-volcanic metasomatism at Oldoinyo Lengai, Tanzania. PhD Dissertation, University College London, UK

Castor SB (2008) The Mountain Pass rare-earth carbonatite and associated ultrapotassic rocks, California. Can Mineral 46:779-806

Cesnokov B, Kotrly M, Nisanbajev T (1998) Brennende Abraumhalden und Aufschlüsse im Tscheljabinsker Kohlenbecken - eine reiche Mineralienküche. Mineralien-Welt 9:54-63

Chang LLY (1965) Subsolidus phase relations in the systems $\mathrm{BaCO}_{3}-\mathrm{SrCO}_{3}, \mathrm{SrCO}_{3}-\mathrm{CaCO}_{3}$, and $\mathrm{BaCO}_{3}$ $\mathrm{CaCO}_{3}$. J Geol 73:346-368

Chang LLY, Howie RA, Zussman J (1997) Rock-Forming Minerals. Volume 5B, 2nd Edition. Non-Silicates: Sulphates, Carbonates, Phosphates, Halides. Longman Group, Essex, UK

Chapelle FH, O'Neill K, Bradley PM, Methé BA, Ciufo SA, Knobel LL, Lovley DR (2002) A hydrogen-based subsurface microbial community dominated by methanogens. Nature 415:312-314

Chou I, Sharma A, Burruss RC, Shu J, Mao HK, Hemley RJ, Goncharov AF, Stern LA, Kirby SH (2000) Transformations in methane hydrates. Proc Natl Acad Sci USA 97:13484-13487

Church AA, Jones AP (1995) Silicate-carbonate immiscibility at Oldoinyo-Lengai. J Petrol 36:869-889

Cleaves HJ II, Crapster-Pregont E, Jonsson CM, Jonsson CL, Sverjensky DA, Hazen RM (2011) The adsorption of short single-stranded DNA oligomers to mineral surfaces. Chemosphere 83:1560-1567

Cloud PE (1962) Environment of calcium carbonate deposition west of Andros Island, Bahamas. US Geol Sury Prof Paper 350:1-138

Cody AM, Cody RD (1991) Chiral habit modifications of gypsum from epitaxial-like adsorption of stereospecific growth inhibitors. J Cryst Growth 113:508-529

Cody GD (2004) Transition metal sulfides and the origins of metabolism. Ann Rev Earth Planet Sci 32:569-599

Cody GD, Boctor NZ, Brandes JA, Filley TL, Hazen RM, Yoder HS Jr (2004) Assaying the catalytic potential of transition metal sulfides for abiotic carbon fixation. Geochim Cosmochim Acta 68:2185-2196

Cody GD, Boctor NZ, Filley TR, Hazen RM, Scott JH, Yoder HS Jr (2000) The primordial synthesis of carbonylated iron-sulfur clusters and the synthesis of pyruvate. Science 289:1339-1342

Cody GD, Boctor NZ, Hazen RM, Brandes JA, Morowitz HJ, Yoder HS Jr (2001) Geochemical roots of autotrophic carbon fixation: Hydrothermal experiments in the system citric acid, $\mathrm{H}_{2} \mathrm{O}-( \pm \mathrm{FeS})-( \pm \mathrm{NiS})$ Geochim Cosmochim Acta 65:3557-3576

Coes L Jr (1962) Synthesis of minerals at high pressures. In: Modern Very High Pressure Techniques. Wentorf RH (ed) Butterworths, Washington, p 137-150

Coleman RG, Lee DE (1962) Metamorphic aragonite in the glaucophane schists of Cazadero, California. Am J Sci 260:577-595

Colwell FS, D'Hondt S (2013) Nature and extent of the deep biosphere. Rev Mineral Geochem 75:547-574 Cowlard FC, Lewis JC (1967) Vitreous carbon-a new form of carbon. J Mater Sci 2:507-512, doi: 10.1007/ BF00752216

Cox KG (1980) Kimberlite and carbonatite magmas. Nature 283:716-717

D’Hondt S, Jørgensen BB, Miller DJ, Batzke A, Blake R, Cragg BA, Cypionka H, Dickens GR, Ferdelman T, Hinrichs K-U, Holm NG, Mitterer R, Spivack A, Wang G, Bekins B, Engelen B, Ford K, Gettemy G, Rutherford SD, Sass H, Skilbeck CG, Aiello IW, Guèrin G, House CH, Inagaki F, Meister P, Naehr T, Niitsuma S, Parkes RJ, Schippers A, Smith DC, Teske A, Wiegel J, Naranjo Padilla C, Solis Acosta JL (2004) Distributions of microbial activities in deep subseafloor sediments. Science 306:2216-2221, doi: $10.1126 /$ science. 1101155 
Dai M, Shi N, Ma Z, Xiong M, Bai W, Fang Q, Yan B, Yang J (2004) Crystal structure determination of tongbaite. Acta Mineral Sinica 24:1-6

Dana ES (1884) A crystallographic study of the thinolite of Lake Lahontan. US Geol Surv Bull 12:429-450 Dana ES (1958) A Textbook of Mineralogy, $4^{\text {th }}$ edition. John Wiley \& Sons, New York

Dasgupta R (2013) Ingassing, storage, and outgassing of terrestrial carbon through geologic time. Rev Mineral Geochem 75:183-229

Dasgupta R, Hirschmann MM, Smith ND (2007) Water follows carbon: $\mathrm{CO}_{2}$ incites deep silicate melting and dehydration beneath midocean ridges. Geology 35:135-138, doi: 10.1130/G22856A.1

Daulton TL, Bernatowicz TJ, Lewis RS, Messenger S, Stadermann FJ, Amari S (2003) Polytype distribution of circumstellar silicon carbide: microstructural characterization by transmission electron microscopy. Geochim Cosmochim Acta 67:4743-4767

Davies G (1984) Diamond. Adam Hilger, Bristol, UK

Dawson JB (1962) Sodium carbonate lavas from Oldoinyo Lengai, Tanganyika. Nature 195:1075-1076

Dawson JB (1966) Oldoinyo Lengai-an active volcano with sodium carbonatite lava flows. In: Carbonatites. Tuttle OF, Gittins J (edd) Wiley Interscience, New York, p 155-168

Dawson JB, Pinkerton H, Norton GE, Pyle DM (1990) Physicochemical properties of alkali carbonatite lavas: data from the 1988 eruption of Oldoinyo Lengai, Tanzania. Geology 18:260-263.

Day HW (2012) A revised diamond-graphite transition curve. Am Mineral 97:52-62

Deans T (1966) Economic mineralogy of African carbonatites. In: Carbonatites. Tuttle OF, Gittins J (eds) Wiley Interscience, New York, p 385-413

DeCarli PS, Jamieson JC (1961) Formation of diamond by explosive shock. Science 133:1821-1823

Deer WA, Howie RA, Zussman J (1966) An Introduction to Rock-Forming Minerals. John Wiley \& Sons, New York

Derjaguin BV, Fedoseev DV (1968) The synthesis of diamond at low pressures. Sci Am 233:102-109

Di Pierro S, Gnos E, Grobérty BH, Armbruster T, Bernasconi SM, Ulmer P (2003) Rock-forming moissanite (natural $\alpha$-silicon carbide). Am Mineral 88:1817-1821

Dollase WA, Reeder RJ (1986) Crystal structure refinements of huntite, $\mathrm{CaMg}_{3}\left(\mathrm{CO}_{3}\right)_{4}$, with X-ray powder data. Am Mineral 71:163-166

Dove PM (2010) The rise of skeletal biomineralization. Elements 6:37-42

Dove PM, De Yoreo JJ, Weiner S (eds) (2003) Biomineralization. Reviews in Mineralogy and Geochemistry Volume 54. Mineralogical Society of America, Washington, DC

Dunham KC, Wilson AA (1985) Geology of the Northern Penine Orefield, Volume 2. Stainmore to Craven. Economic Memoir, British Geological Survey, London

Dziedzic A, Ryka W (1983) Carbonatites in the Tanjo intrusion (NE Poland). Arch Mineral 38:4-34

Effenberger H, Mereiter K, and Zemann J (1981) Crystal structure of magnesite, calcite, rhodochrosite, siderite, smithsonite, and dolomite, with discussion of some aspects of the stereochemistry of calcium siderite, smithsonite, and dolomite, with d
type carbonates. Z Kristallogr 156:233-243

El Goresy A, Donnay G (1968) A new allotropic form of carbon from the Ries crater. Science 161:363-364, doi: $10.1126 /$ science. 161.3839 .363

El Goresy A, Gillet P, Chen M, Künstler F, Graup G, Stähle V (2001) In situ discovery of shock-induced graphite-diamond phase transition in gneisses from the Ries crater, Germany. Am Mineral 86:611-621

Ernst WG (1965) Mineral paragenesis in Franciscan metamorphic rocks, Panoche Pass, California. Am Mineral 61:1005-1008

Ernston K, Mayer W, Neumair A, Rappenglück B, Rappenglück MA, Sudhaus D, Zeller KW (2010) The Cheimgau crater strewn field: evidence of a Holocene large impact event in southeastern Bavaria, Germany. J Siberian Fed Univ Eng Technol 1:72-103

Ertem G, Ferris JP (1996) Synthesis of RNA oligomers on heterogeneous templates. Nature 379:238-240

Essene EJ (1983) Solid solutions and solvi among metamorphic carbonates with applications to geological hermobarometry. Rev Mineral 11:77-96

Ettmayer P, Lengauer W (1994) Carbides: transition metal solid state chemistry. In: Encyclopedia of Inorganic Chemistry. King RB (ed) John Wiley \& Sons, New York

Evgenii K, Wolfram T (2000) The role of quartz in the origin of optical activity on Earth. Origins Life Evol Biosphere 30:431-434

Falini G, Albeck S, Weiner S, Addadi L (1996) Control of aragonite or calcite polymorphism by mollusk shell macromolecules. Science 271:67-69

Fang Q, Bai W, Yang J, Xu X, Li G, Shi N, Xiong M, Rong H (2009) Qusongite (WC): a new mineral. Am Mineral 94:387-390

Ferris JP (2005) Mineral catalysis and prebiotic synthesis: montmorillonite-catalyzed formation of RNA Elements 1:145-149

Ferris JP, Hill AR, Liu R, Orgel LE (1996) Synthesis of long prebiotic oligomers on mineral surfaces. Nature 381:59-61

Field JE (ed) (1979) The Properties of Diamond. Academic Press, New York
Frank FC (1949) The influence of dislocations on crystal growth. Discuss Faraday Soc No. 5:48-54

Frank FC (1951) The growth of carborundum: dislocations and polytypism. Philos Mag 42:1014-102

Franz AK (2007) The synthesis of biologically active organosilicon small molecules. Curr Opin Drug Discovery Dev 10:654-671

Freund F, Staple A, Scoville J (2001) Organic protomolecule assembly in igneous minerals. Proc Natl Acad Sci USA 98:2142-2147

Frisia S, Borsato A, Fairchild AJ, McDermott F (2000) Calcite fabrics, growth mechanisms, and environments of formation in speleothems from the Italian Alps and SW Ireland. J Sediment Res 70:1183-1196

Frondel C, Marvin UB (1967) Lonsdaleite, a hexagonal polymorph of diamond. Nature 214:587-589, doi: $10.1038 / 214587 \mathrm{a} 0$

Garson MS, Morgan DJ (1978) Secondary strontianite at Kangankunde carbonatite complex, Malawi. Trans Inst Min Metall 87B:70-73

Geim AK (2009) Graphene: status and prospects. Science 234:1530-1534, doi: 10.1126/science.1158877

Geim AK, Novoselov KS (2007) The rise of graphene. Nature Mater 6:183-191

Generalov ME, Naumov VA, Mokhov AV, Trubkin NV (1998) Isovite $(\mathrm{Cr}, \mathrm{Fe})_{23} \mathrm{C}_{6}$-a new mineral from the gold-platinum bearing placers of the Urals. Zap Vseross Mineral O-va 127:26-37

Gilmour I, French BM, Franchi IA, Abbott JI, Hough RM, Newton J, Koeberl C (2003) Geochemistry of carbonaceous impactites from the Gardnos impact structure, Norway. Geochim Cosmochim Acta 67:3889-3903

Glein C (2012) Theoretical and experimental studies of cryogenic and hydrothermal organic geochemistry. $\mathrm{PhD}$ Dissertation, Arizona State University, Tempe, Arizona

Gold T (1999) The Deep Hot Biosphere. Copernicus, New York

Goldschmidt VM (1952) Geochemical aspects of the origin of complex organic molecules on the earth, as precursors to organic life. New Biol 12:97-105

Goodrich CA (1984) Phosphoran pyroxene and olivine in silicate inclusions in natural iron-carbon alloy, Disko Island, Greenland. Geochim Cosmochim Acta 48:1115-1126

Goodrich CA, Bird JM (1985) Formation of iron-carbon alloys in basaltic magma at Uivfaq, Disko Island: the role of carbon in mafic magmas. J Geol 93:475-492

Gorshkov AI, Bao YN, Bersho LN, Ryabchikov ID, Sivtsov AV, Lapina MI (1997) Inclusions of native metals and other minerals in diamond from kimberlite pipe 50, Liaoning, China. Int Geol Rev 8:794-804

Grace J, Collett T, Colwell F, Englezos P, Jones E, Mansell R, Meekison JP, Ommer R, Pooladi-Darvish M, Riedel M, Ripmeester JA, Shipp C, Willoughby E (2008) Energy from gas hydrates-assessing the opportunities and challenges for Canada. Report of the Expert Panel on Gas Hydrates, Council of Canadian Academies, September 2008

Grew ES, Bada JL, Hazen RM (2011) Borate minerals and origin of the RNA world. Origins Life Evol Biospheres 41:307-316, doi 10.1007/s11084-101-9233-y

Grotzinger JP, Read JF (1983) Evidence for primary aragonite precipitation, lower Proterozoic (1.9 Ga) dolomite, Wopmay orogen, northwest Canada. Geology 11:710-713

Gübelin EJ, Koivula JI (2008) Photoatlas of Inclusions in Gemstones. Opino, Basel, Switzerland

Guggenheim S, Koster van Groos AF (2003) New gas-hydrate phase: synthesis and stability of clay-methane hydrate intercalate. Geology 31:653-656, doi:10.1130/0091-7613(2003)031<0653:NGPSAS >2.0.CO;2

Gunasekaran S, Anbalagan G, Pandi S (2006) Raman and infrared spectra of carbonates of calcite structure. J Raman Spectrosc 37:892-899

Gusev AI, Rempel AA, Lipatnikov VN (1996) Incommensurate ordered phase in non-stoichiometric tantalum carbide. J Phys Condens Matter 8:8277-8293

Hall HT (1970) Personal experiences in high pressure. The Chemist July 1970:276-279

Harlow GE (ed) (1998) The Nature of Diamonds. Cambridge University Press, New York

Hassel O, Mark H (1924) Über die Kristallstruktur des Graphits. Z Phys 25:317-337

Hatano M, Ohsaki T, Arakawa K (1985) Graphite whiskers by new process and their composites, advancin technology in materials and processes. Science of Advanced Materials and Processes, National SAMPE Symposium 30:1467-1476

Hayes JM, Waldbauer JR (2006) The carbon cycle and associated redox processes through time. Philos Trans R Soc London 361:931-950

Hazen RM (1999) The Diamond Makers. Cambridge University Press, New York

Hazen RM (2005) Genesis: The Scientific Quest for Life's Origin. Joseph Henry Press, Washington, DC

Hazen RM (2006) Mineral surfaces and the prebiotic selection and organization of biomolecules. Am Minera 91:1715-1729 Hazen RM, Ewing RC, Sverjensky DA (2009) Evolution of uranium and thorium minerals. Am Mineral 94:1293-1311

Hazen RM, Downs RT, Kah, L, Sverjensky D (2013) Carbon mineral evolution. Rev Mineral Geochem 75:79107

Hazen RM, Filley TR, Goodfriend GA (2001) Selective adsorption of L- and D-amino acids on calcite: implications for biochemical homochirality. Proc Natl Acad Sci USA 98:5487-5490 
Hazen RM, Hemley RJ, Mangum AJ (2012) Carbon in Earth's interior: storage, cycling, and life. Eos Trans Am Geophys Union 93:17-28

Hazen RM, Papineau D, Bleeker W, Downs RT, Ferry JM, McCoy TJ, Sverjensky DA, Yang H (2008) Mineral evolution. Am Mineral 93:1693-1720

Heimann RB, Evsyukov SE, Kavan L (eds) (1999) Carbyne and Carbynoid Structures. Physics and Chemistry of Materials with Low-Dimensional Structures, Volume 21. Kluwer Academic, Dordrecht, The Netherlands Helgeson HC, Richard L, McKenzie WF, Norton DL, Schmitt A (2009) A chemical and thermodynamic model of oil generation in hydrocarbon source rocks. Geochim Cosmochim Acta 73:594-695

Hendricks BS (1930) The crystal structure of cementite. Z Kristallogr 74:534-545

Hill AR, Böhler C, Orgel LE (1998) Polymerization on the rocks: negatively-charged $\alpha$-amino acids. Origins Life Evol Biosphere 28:235-243

Holland HD (1984) The Chemical Evolution of the Oceans and Atmosphere. Princeton University Press, Princeton, New Jersey

Holm NG, Ertem G, Ferris JP (1993) The binding and reactions of nucleotides and polynucleotides on iron oxide hydroxide polymorphs. Origins Life Evol Biosphere 23:195-215

Hough RM, Gilmour I, Pillinger CT, Arden JW, Gilkess KWR, Yuan J, Milledge HJ (1995) Diamond and silicon carbide in impact melt rock from the Ries impact crater. Nature 378:41-44

Hough RM, Gilmour I, Pillinger CT, Langenhorst F, Montanari A (1997) Diamonds from the iridium-rich K-T boundary layer at Arroyo el Mimbral, Tamaulipas, Mexico. Geology 25:1019-1022

Huber C, Wächtershäuser G (1998) Peptides by activation of amino acids with $\mathrm{CO}$ on $(\mathrm{Ni}, \mathrm{Fe}) \mathrm{S}$ surfaces: implications for the origin of life. Science 281:670-672

Hull AW (1917) A new method of x-ray crystal analysis. Phys Rev 10:661-696

Hyndman RD, Davis EE (1992) A mechanism for the formation of methane hydrate and sea-floor bottomsimulating reflectors by vertical fluid expulsion. J Geophys Res 97:7025-704

Hyndman RD, Spence GD (1992) A seismic study of methane hydrate marine bottom simulating reflectors. J Geophys Res 97:6683-6698

Irifune T, Hemley RJ (2012) Synthetic diamond opens windows into the deep Earth. Eos Trans Am Geophys Union 93:65-66

Jagodzinski H (1954a) Fehlordnungserscheinungen und ihr Zusammenhang mit der Polytypie des SiC. Neues Jahrb Mineral Monatsh 1954:49-65

Jagodzinski H (1954b) Polytypism in SiC crystals. Acta Crystallogr 7:300
James NP, Narbonne GM, Sherman AB (1998) Molar-tooth carbonates: shallow subtidal facies of the Mid- to Late Proterozoic. J Sediment Res 68:716-722

Jana D, Walker D (1997) The impact of carbon on element distribution during core formation. Geochim Cosmochim Acta 61:2759-2763

Javoy M (1997) The major volatile elements of the Earth: their origin, behavior, and fate. Geophys Res Lett 24:177-180, doi: 10.1029/96GL03931

Jehlička J, Žáček V, Edwards HGM, Shcherbakova E, Moroz T (2007) Raman spectra of organic compounds kladnoite $\left(\mathrm{C}_{6} \mathrm{H}_{4}(\mathrm{CO})_{2} \mathrm{NH}\right)$ and hoelite $\left(\mathrm{C}_{14} \mathrm{H}_{8} \mathrm{O}_{2}\right)$ : rare sublimation products crystallising on self-ignited coal heaps. Spectrochim Acta A68:1053-1057

Jones AP, Genge M, Carmody L (2013) Carbonate melts and carbonatites. Rev Mineral Geochem 75:289-322 Jones AP, Kearsley AT, Friend CRL, Robin E, Beard A, Tamura A, Trickett S, Claeys P (2005) Are there signs of a large Paleocene impact preserved around Disko Bay, West Greenland? Nuussuaq spherule beds origin by impact instead of volcanic eruption? In: Large Meteorite Impacts III. Special Paper 384. Kenkmann T, Horz F, Deutsch A (eds) Geological Society of America, Boulder, Colo

Jones AP, Wyllie PJ (1986) Solubility of rare earth elements in carbonatite magmas, as indicated by the liquidus surface in $\mathrm{CaCO}_{3}-\mathrm{Ca}(\mathrm{OH})_{2}-\mathrm{La}(\mathrm{OH})_{3}$. Appl Geochem 1:95-102

Jonsson CM, Jonsson CL, Sverjensky DA, Cleaves HJ, Hazen RM (2009) Attachment of L-glutamate to rutile $\left(\mathrm{TiO}_{2}\right)$ : a potentiometric, adsorption, and surface complexation study. Langmuir 25:12127-12135

Kah LC, Bartley JK (2011) Protracted oxygenation of the Proterozoic biosphere. Int Geol Rev 53:1424-1442

ah LC, Sherman AB, Narbonne GM, Kaufman AJ, Knoll AH, James NP (1999) $\delta^{13} \mathrm{C}$ isotope stratigraphy of the Mesoproterozoic Bylot Supergroup, Northern Baffin Island: implications for regional lithostratigraphic correlations. Can J Earth Sci 36:313-332

Kamhi SR (1963) On the structure of vaterite, $\mathrm{CaCO}_{3}$. Acta Crystallogr 16:770-772

Kapustin YL (1980) Mineralogy of Carbonatites. Smithsonian Institution, Washington, DC

Kennedy CS, Kennedy GC (1976) The equilibrium boundary between graphite and diamond. J Geophys Res $81: 2467-2470$

Kennedy MJ, Droser M, Mayer LM, Pevear D, Mrofka D (2006) Late Precambrian oxygenation; inception of the clay mineral factory. Science 311:1446-1449

Kenney JF, Shnyukov YF, Krayishkin VA, Tchebanenko II, Klochko VP (2001) Dismissal of claims of a biological connection for natural petroleum. Energia 22:26-34
Keppler H, Wiedenbeck M, Shcheka SS (2003) Carbon solubility in olivine and the mode of carbon storage in the Earth's mantle. Nature 424:414-416

Kinsman DJJ (1967) Huntite from an evaporate environment. Am Mineral 52:1332-1340

Klein C (2005) Some Precambrian banded iron-formations (BIFs) from around the world: their age, geologic setting, mineralogy, metamorphism, geochemistry, and origin. Am Mineral 90:1473-1499

Klein C, Hurlbut CS Jr (1993) Manual of Mineralogy, $21^{\text {st }}$ edition. Wiley, New York

Knoll AH (2003) Biomineralization and evolutionary history. Rev Mineral Geochem 54:329-356

Koh CA, Sloan ED, Sum AK, Wu DT (2011) Fundamentals and applications of gas hydrates. Ann Rev Chem Biomol Eng 2:237-257

Koh CA, Sum AK, Sloan ED (2009) Gas hydrates: unlocking the energy from icy cages. J Appl Phys 106:061101, doi: $10.1063 / 1.3216463$

Koster van Groos AF, Guggenheim S (2009) The stability of methane hydrate intercalates of montmorillonite and nontronite: implications for carbon storage in ocean-floor environments. Am Mineral 94:372-379

Kramers JD, Smith CB, Lock NP, Harmon RS, Boyd FR (1981) Can kimberlites be generated from an ordinary mantle? Nature 291:53-56

Krishna P, Verma AR (1965) On deduction of silicon-carbide polytypes from screw dislocations. Z Kristallogr 121:36-54

Kroto HW, Heath JR, O'Brien SC, Curl RF, Smalley RE (1985) C60: Buckminsterfullerene. Nature 318:162163

Kutcherov VG, Bendiliani NA, Alekseev VA, Kenney JF (2002) Synthesis of hydrocarbons from minerals at pressure up to 5 GPa. Proc Russian Acad Sci 387:789-792

Kvenvolden KA (1995) A review of the geochemistry of methane in natural gas hydrate. Org Geochem 23:9971008

Lahav N (1999) Biogenesis: Theories of Life's Origin. Oxford University Press, New York

Langenhorst F, Deutsch A (2012) Shock metamorphism of minerals. Elements 8:31-36

Langenhorst F, Shafranovsky GI, Masaitis VL, Koivisto M (1999) Discovery of impact diamonds in a Fennoscandian crater and evidence for their genesis by solid-state transformation. Geology 27:747-750

Larsen LM, Pedersen AK (2009) Petrology of the Paleocene picrites and flood basalts in Disko and Nuussuaq West Greenland. J Petrol 50:1667-1711

Lattimer JM, Grossman L (1978) Chemical condensation sequences in supernova ejecta. Moon Planets 19:169-184

Le Bail A, Ouhenia S, Chateigner D (2011) Microtwinning hypothesis for a more ordered vaterite model. Powder Diffr 26:16-21

Le Bas MJ, Keller J, Kejie T, Wall F, Williams CT, Peishan Z (1992) Carbonatite dykes at Bayan Obo, Inner Mongolia, China. Mineral Petrol 46:195-228

Lee J-S, Yu S-C, Bai W-J, Yang J-S, Fang Q-S, Zhang Z (2006) The crystal structure of natural 33R moissanite from Tibet. Z Kristallogr 221:213-217

Leung I (1990) Silicon carbide cluster entrapped in a diamond from Fuxian, China. Am Mineral 75:1110-1119 Leung I, Guo W, Friedman I, Gleason J (1990) Natural occurrence of silicon carbide in a diamondiferous kimberlite from Fuxian. Nature 346:352-354

Lewis HC (1887) On a diamantiferous peridotite, and the genesis of diamond. Geol Mag 4:22-24

Liang Q, Yan CS, Meng Y, Lai L, Krasnicki S, Mao H-K, Hemley RJ (2009) Recent advances in high-growth rate single crystal CVD diamond. Diamond Rel Mater 18:698-703

Lyakhov AO, Oganov AR (2011) Evolutionary search for superhard materials applied to forms of carbon and $\mathrm{TiO}_{2}$. Phys Rev B 84:092103

Lyakhovich VV (1980) Origin of accessory moissanite. Int Geol Rev 22:961-970

Mackenzie FT, Bischoff WD, Bishop FC, Loijens M. Schoonmaker J, Wollast R (1983) Magnesian calcites: low-temperature occurrence, solubility and solid-solution behavior. Rev Mineral Geochem 11:97-144

Madar R (2004) Materials science: silicon carbide in contention. Nature 430:974-975 doi: 10.1038/430974a.

Mamedov KM (1963) Barite-witherite mineralization in mountain regions of the Turkmen, S.S.R. Ivz Akad Nauk Turkm SSR, Ser Fiz-Tekh, Khim Geol Nauk 1:78-82

Manning CE, Shock EL, Sverjensky D (2013) The chemistry of carbon in aqueous fluids at crustal and uppermantle conditions: experimental and theoretical constraints. Rev Mineral Geochem 75:109-148

Markgraf SA, Reeder RJ (1985) High-temperature structure refinements of calcite and magnesite. Am Mineral 70:590-600

Mathez EA, Fogel RA, Hutcheon ID, Marshintsev VK (1995) Carbon isotopic composition and origin of SiC from kimberlites of Yakutia [Sakha], Russia. Geochim Cosmochim Acta 59:781-791

Max MD (2003) Natural Gas Hydrate in Oceanic and Permafrost Environments. Kluwer Academic Publishers, Dordrecht

McCammon CA, Satchel T, Harris JW (2004) Iron oxidation state in lower mantle assemblages II. Inclusions in diamonds from Kankan, Guinea. Earth Planet Sci Lett 222:423-434 
McCollom TM (2013) Laboratory simulations of abiotic hydrocarbon formation in Earth's deep subsurface. Rev Mineral Geochem 75:467-494

McCollom TM, Simoneit BR (1999) Abiotic formation of hydrocarbons and oxygenated compounds during thermal decomposition of iron oxalate. Origins Life Evol Biosphere 29:167-186, doi: 10.1023/A:1006556315895

McDonough WF (2003) Compositional model for the Earth's core. In: Treatise on Geochemistry. Vol. 2. Mantle and Core. Carlson RW (ed) Elsevier, Oxford, UK, p 547-568

McGreegor RB, Pingitore NE, Lytle FW (1997) Strontianite in coral skeletal aragonite. Science 275:14521454

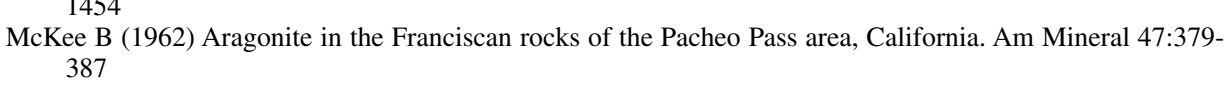

McKee DW (1973) Carbon and graphite science. Ann Rev Mater Sci 3:195-231

McKie D, Frankis EJ (1977) Nyererite: a new volcanic carbonate mineral from Oldoinyo Lengai, Tanzania. Z Kristallogr 145:73-95

Meersman F, Daniel I, Bartlett DH, Winter R, Hazael R, McMillain PF (2013) High-pressure biochemistry and biophysics. Rev Mineral Geochem 75:607-648

Megaw HD (1973) Crystal Structures: A Working Approach. Saunders, Philadelphia

Mellor JW (1924) Chapter 39: Carbon. In: A Comprehensive Treatise on Inorganic and Theoretical Chemistry. Longmans, London, p $710-771$

Melson WG, Switzer G (1966) Plagioclase-spinel-graphite xenoliths in metallic iron-bearing basalts, Disko Island, Greenland. Am Mineral 51:664-676

Meng YF, Yan CS, Kransicki S, Liang Q, Lai J, Shu H, Yu T, Steele AS, Mao H-K, Hemley RJ (2012) High optical quality multicarat single crystal diamond produced by chemical vapor deposition. Phys Status Solidi A 209:101-104

Mikhail S (2011) Stable isotope fractionation during diamond growth and the Earth's deep carbon cycle. Ph.D thesis. University College London, UK

Mikhail S, Jones AP, Hunt SA, Guillermier C, Dobson DP, Tomlinson E, Dan H, Milledge H, Franchi I, Wood I, Beard A, Verchovsky S (2010). Carbon isotope fractionation between natural Fe-carbide and diamond; a light $\mathrm{C}$ isotope reservoir in the deep Earth and core? American Geophysical Union, Fall Meeting 2010, Abstract U21A-0001

Mikhail S, Shahar A, Hunt SA, Jones AP, Verchovsky AB (2011) An experimental investigation of the pressure effect on stable isotope fractionation at high temperature; implications for mantle processes and core formation in celestial bodies. Lunar Planet Sci Conf 42:1376

Milkov AV (2004) Global estimates of hydrate-bound gas in marine sediments: how much is really out there? Earth Sci Rev 66:183-197, doi:10.1016/j.earscirev.2003.11.002

Mills SJ, Hatert F, Nickel EH, Ferraris G (2009) The standardisation of mineral group hierarchies: application to recent nomenclature proposals. Eur J Mineral 21:1073-1080, doi: 10.1127/0935-1221/2009/0021-1994 Mitchell RH (1995) Kimberlites, Orangeites, and Related Rocks. Plenum, New York

Mitchell RS, Phaar RF (1961) Celestite and calciostrontianite from Wise County, Virginia. Am Mineral 46:189-195

Moissan H (1904a) The Electric Furnace. Edward Arnold, London

Moissan H (1904b) Nouvelles recherches sur la météorité de Cañon Diablo. Comptes Rendus 139:773-786

Momma K, Ikeda T, Nishikubo K, Takahashi N, Honma C, Takada M, Furukawa Y, Nagase T, Kudoh Y (2011) New silica clathrate minerals that are isostructural with natural gas hydrates. Nature Commun 2:196-197

Moore RO, Gurney JJ (1989) Mineral inclusions in diamond from the Monastery kimberlite, South Africa Spec Publ Geol Surv Australia 14:1029-1041

Morgan P (2005) Carbon Fibers and their Composites. CRC Press, Boca Raton, Florida

Morse JW, Andersson AJ, Mackenzie FT (2006) Initial responses of carbonate-rich shelf sediments to rising atmospheric $\mathrm{pCO}_{2}$ and "ocean acidification": role of high Mg-calcites. Geochim Cosmochim Acta 70:5814-5830

Morse JW, Mackenzie FT (1990) Geochemistry of Sedimentary Carbonates. Elsevier, Amsterdam

Mrose ME, Rose HJ, Marinenko JW (1966) Synthesis and properties of fairchildite and buetschliite: their relationship in wood-ash stone formation. Geol Soc Am Spec Paper 101:146

Mugnaioli E, Andrusenko I, Schüler T, Loges N, Dinnebier RE, Panthöfer M, Tremel W, Kolb U (2012) Abinitio structure determination of vaterite by automated electron diffraction. Angew Chem 124:7148-7152, doi: 10.1002/anie. 200123456

Nadler MR, Kempter CP (1960) Some solidus temperatures in several metal-carbon systems. J Phys Chem 64:1468-1471

Nasibulin AG, Pikhitsa PV, Jiang H, Brown DP, Krasheninnikov AV, Anisimov AS, Queipo P, Moisala A, Gonzalez D, Lientschnig G, Hassanien A, Shandakov SD, Lolli G, Resasco DE, Choi M, Tomanek D, Kauppinen EI (2007). A novel hybrid carbon material. Nature Nanotechnol 2:156-161.
Nawrocki, J. (1997) The silanol group and its role in liquid chromatography. J Chromatogr A779:29-71

Ni H, Keppler H (2013) Carbon in silicate melts. Rev Mineral Geochem 75:251-287

Nicheng S, Bai W, Li G, Xiong M, Fang Q, Yang J, Ma Z, Rong H (2008) Yarlongite: a new metallic carbide mineral. Acta Geol Sinica 83:52-56

Nicheng S, Ma Z, Xiong M, Dai M, Bai W, Fang Q, Yan B, Yang J (2005) The crystal structure of $\left(\mathrm{Fe}_{4} \mathrm{Cr}_{4} \mathrm{Ni}_{9}\right)_{9} \mathrm{C}_{4}$ Sci China Ser D Earth Sci 48:338-345

Nordenskiöld AE (1872) Account of an expedition to Greenland in the year 1870. Geol Mag 9:289-306, 355$368,409-427,449-463,516-524$

Novgorodova MI, Generalov ME, Trubkin NV (1997) The new TaC-NbC isomorphic row and niobocarbide-a new mineral from platinum placers of the Urals. Proc Russian Mineral Soc 126:76-95

Oganov AR, Hemley RJ, Hazen RM, Jones AP (2013) Structure, bonding, and mineralogy of carbon at extreme conditions. Rev Mineral Geochem 75:47-77

Oleynikov BV, Okrugin AV, Tomshin MD (1985) Native Metals Formation in Basic Rocks of the Siberian Platform. Yakutian Branch of the Soviet Academy of Science, Yakutsk

Olson JC, Shawe DR, Pray LC, Sharp WN (1954) Rare-earth mineral deposits of the Mountain Pass district, San Bernardino County, California. US Geol Surv Prof Paper 261

Orgel LE (1998) Polymerization on the rocks: theoretical introduction. Origins Life Evol Biosphere 28:227234

Orme CA, Noy A, Wierzbicki A, McBride MT, Grantham M, Teng HH, Dove PM, DeYoreo JJ (2001) Formation of chiral morphologies through selective binding of amino acids to calcite surface steps. Nature 411:775-779

Otter ML, Gurney JJ (1989) Mineral inclusions in diamond from the Sloan diatreme, Colorado-Wyoming state line kimberlite district, North America. Spec Publ Geol Surv Australia 14:1042-1053

Pan Z, Sun H, Zhang Y, Chen C (2009) Harder than diamond: superior indentation strength of wurtzite BN and lonsdaleite. Phys Rev Lett 102:055503, doi: 10.1103/PhysRevLett.102.055503

Pandey D, Krishna P (1975a) A model for the growth of anomalous polytype structures in vapour grown SiC. J Cryst Growth 31:66-71

Pandey D, Krishna P (1975b) Influence of stacking faults on the growth of polytype structures II. Silicon carbide polytypes. Philos Mag 31:1133-1148

Pandey D, Krishna P (1978) Advances in Crystallography Oxford and IBH, New Delhi, India

Parkes RJ, Craig BA, Bale SJ, Getiff JM, Goodman K, Rochelle PA, Fry JC, Weightman AJ, Harvey SM (1993) Deep bacterial biosphere in Pacific Ocean sediments. Nature 371:410-413

Parsons I, Lee MR, Smith JV (1998) Biochemical evolution II: Origin of life in tubular microstructures in weathered feldspar surfaces. Proc Natl Acad Sci USA 95:15173-15176

Pasek MA, Dworkin JP, Lauretta DS (2007) A radical pathway for organic phosphorylation during schreibersite corrosion with implications for the origin of life. Geochim Cosmochim Acta 71:1721-1736

Pauly H (1969) White cast iron with cohenite, schreibersite, and sulphides from the Tertiary basalts on Disko, Greenland. Medd Dansk Geol Foren 19:8-30

Pearson DG, Canil D, Shirey SB (2007) Mantle samples included in volcanic rocks: xenoliths and diamonds. In: Treatise on Geochemistry. Vol. 2. Mantle and Core. Carlson RW (ed) Elsevier, Oxford, UK, p 171-275 Pedersen AK (1979) Basaltic glass with high-temperature equilibrated immiscible sulphide bodies with native iron from Disko, central West Greenland. Contrib Mineral Petrol 69:397-407

Pedersen AK (1981) Armalcolite-bearing Fe-Ti oxide assemblages in graphite-equilibrated salic volcanic rodersen AK (1981) Armalcolite-bearing Fe-Ti oxide assemblages in graphite-equilibrated salic
rocks with native iron from Disko, central West Greenland. Contrib Mineral Petrol 77:307-324

Perry RS, Mcloughlin N, Lynne BY, Sephton MA, Oliver JD, Perry CC, Campbell K, Engel MH, Farmer JD, Brasier MD, Staley JT (2007) Defining biominerals and organominerals: direct and indirect indicators of life. Sediment Geol 201:157-179

Pitsch S, Eschenmoser A, Gedulin B, Hui S, Arrhenius G (1995) Mineral induced formation of sugar phosphates. Origins Life Evol Biosphere 25:297-334

Plummer LN, Busenberg E, Glynn PD, Blum AE (1992) Dissolution of strontiantire solid solutions in nonstoichiometric $\mathrm{SrCO}_{3}-\mathrm{CaCO}_{3}-\mathrm{CO}_{2}-\mathrm{H}_{2} \mathrm{O}$ solutions. Geochim Cosmochim Acta 56:3045-3072

Pollock MD, Kah LC, Bartley JK (2006) Morphology of molar-tooth structures in Precambrian carbonates: influence of substrate rheology and implications for genesis. J Sediment Res 76:310-323

Price GD, Yeomans JM (1984) The application of the ANNNI model to polytypic behaviour. Acta Crystallogr B40:448-454

Qi XX, Yang ZQ, Xu JS, Bai WJ, Zhang ZM, Fang QS (2007) Discovery of moissanitein retrogressive eclogite from the pre-pilot hole of the Chinese Continental Drilling Program (CCSD-PP2) and its geological implication. Acta Petrol Sinica 23:3207-3214

Rastsvetaeva RK, Yu D, Pushcharovsky DY, Furmanova NG, Sharp H (1996) Crystal and molecular structure of $\mathrm{Cu}(\mathrm{II})$ succinate monohydrate or "Never wash copper minerals with detergents". Z Kristallogr 211:808811 
Reeder RJ (1983b) Crystal chemistry of the rhombohedral carbonates. Rev Mineral 11:1-47

Reeder RJ (ed) (1983a) Carbonates: Mineralogy and Chemistry. Rev Mineral, Vol 11. Mineralogical Society of America, Washington, DC

Ricardo A, Carrigan MA, Olcott AN, Benner SA (2004) Borate minerals stabilize ribose. Science 303:196

Robinson PT, Malpas J, Cameron S, Zhou MF, Bai WJ (2001) An ultrahigh presure mineral assemblage from the Luobusa Ophiolite, Tibet. Eleventh Annual V. M. Goldschmidt Conference, Abstract 3138

Rode AV, Gamaly EG, Luther-Davies B (2000) Formation of cluster-assembled carbon nanofoam by highrepetition-rate laser ablation. Appl Phys A Mater Sci Process A70:135-144, doi: 10.1007/s003390050025

Rossini FD, Jessup RS (1938) Heat and free energy of formation of carbon dioxide, and of the transition between graphite and diamond. J Res Natl Bur Stand USA 21:491-513

Roussel EG, Cambon Bonavita M-A, Querellou J, Cragg BA, Webster G, Prieur D, Parkes RJ (2008) Extending the sub-sea-floor biosphere. Science 320:1046, doi: 10.1126/ science.1154545

Ruberti E, Gaston ER, Gomes CB, Comin-Chiaramonti P (2008) Hydrothermal REE fluorocarbonate mineralization at Barra do Itapirapua, a multiple stockwork carbonatite, southern Brazil. Can Minera 46:901-914

Rucker JB, Carver RE (1969) A survey of the carbonate mineralogy of Cheilostome Bryozoa. J Paleonto 43:791-799

Rumble D III, Duke EF, Hoering TC (1986) Hydrothermal graphite in New Hampshire: evidence of carbon mobility during regional metamorphism. Geology 14:452-455

Rumble D III, Hoering TC (1986) Carbon isotope geochemistry of graphite vein deposits from New Hampshire, U. S. A. Geochim Cosmochim Acta 50:1239-1247

Rundel R (2001) Polycyclic aromatic hydrocarbons, phthalates, and phenols. In: Indoor Air Quality Handbook. Spengler JD, Samet JM, McCarthy JF (eds) McGraw-Hill, New York, p 34.1-34.2

Russell MJ, Daniel RM Hall AJ, Sherringham J (1994) A hydrothermally precipitated catalytic iron-sulphide membrane as a first step toward life. J Mol Evol 39:231-243

Russell MJ, Hall AJ (1997) The emergence of life from iron monosulphide bubbles at a submarine hydrothermal redox and $\mathrm{pH}$ front. J Geol Soc London 154:377-402

Rutt HN, Nicola JH (1974) Raman spectra of carbonates of calcite structure. J Phys C 7:4522-4528

Saddow SE, Agarwal A (2004) Advances in Silicon Carbide Processing and Applications. Artech House, Norwood, Massachusetts

Sameshima T, Rodgers KA (1990) Crystallography of 6H silicon carbide from Seddonville, New Zealand. Neues Jahrb Mineral Monatsh 1990:137-143

Sano N, Wang H, Chhowalla M, Alexandrou I, Amaratunga GAJ (2001) Synthesis of carbon 'onions' in water. Nature 414:506-507, doi: 10.1038/35107141

Schoonen MAA, Smirnov A, Cohn C (2004) A perspective on the role of minerals in prebiotic synthesis. AMBIO 33:539-551

Schrenk MO, Brazelton WJ, Lang SQ (2013) Serpentinization, carbon, and deep life. Rev Mineral Geochem 75:575-606

Scott HP, Hemley RJ, Mao HK, Hershbach DR, Fried LE, Howard WM, Bastea S (2004) Generation of methane in Earth's mantle: in situ high pressure-temperature measurements of carbon reduction. Proc Natl Acad Sci USA 101:14023-14026, doi: 10.1073/pnas.0405930101

Sephton MA, Hazen RM (2013) On the origins of deep hydrocarbons. Rev Mineral Geochem 75:449-465

Shcheka SS, Wiedenbeck M, Frost DJ, Keppler H (2006) Carbon solubility in mantle minerals. Earth Plane Sci Lett 245:730-742

Shearman DJ, Smith AJ (1985) Ikaite, the parent mineral of jarrowite-type pseudomorphs. Proc Geol Assoc 96:305-314

Sherwood-Lollar B, Westgate TD, Ward JA, Slater GF, Lacrampe-Couloume G (2002) Abiogenic formation of alkanes in the Earth's crust as a minor source for global hydrocarbon reservoirs. Nature 416:522-524 Shi N, Bai W, Li G, Xiong M, Fang Q, Yang J, Ma Z, Rong H (2009) Yarlongite: a new metallic carbide mineral. Acta Geol Sinica (Engl Ed) 83:52-56

Shirey SB, Cartigny P, Frost DJ, Keshav S, Nestola F, Nimis P, Pearson DG, Sobolev NV, Walter MJ (2013) Diamonds and the geology of mantle carbon. Rev Mineral Geochem 75:355-42

Shirey SB, Harris JW, Richardson SH, Fouch MJ, James DE, Cartigny P, Deines P, Viljoen F (2002) Diamond genesis, seismic structure, and evolution of the Kaapvaal-Zimbabwe craton. Science 297:1683-1686

Shirey SB, Richardson SH (2011) Start of the Wilson cycle at 3 Ga shown by diamonds from the subcontinental mantle. Science 333:434-436, doi: 10.1126/science.1206275

Shiryaev AA, Griffin WL, Stoyanov E (2011) Moissanite (SiC) from kimberlites: polytypes, trace elements, inclusions and speculations on origin. Lithos 122:152-16

Shvartsburg AA, Hudgins RR, Gutierrez R, Jungnickel G, Frauenheim T, Jackson KA, Jarrold MF (1999) Balland-chain dimers from a hot fullerene plasma. J Phys Chem 103:5275-5284

Skinner BJ, Appleman DE (1963) Melanophlogite, a cubic polymorph of silica. Am Mineral 48:854-867
Smith G (1926) A contribution to the mineralogy of New South Wales. Geol Surv New South Wales Mineral Res 34:1-145

Smith JV (1998) Biochemical evolution. I. Polymerization on internal, organophilic silica surfaces of dealuminated zeolites and feldspars. Proc Natl Acad Sci USA 95:3370-3375

Smith JV, Arnold FP Jr, Parsons I, Lee MR (1999) Biochemical evolution III: Polymerization on organophilic silica-rich surfaces, crystal-chemical modeling, formation of first cells, and geological clues. Proc Natl Acad Sci USA 96:3479-3485

Soldati AL, Jacob DE, Wehrmeister U (2008) Structural characterization and chemical composition of aragonite and vaterite in freshwater cultured pearls. Mineral Mag 72:579-592

Sommer H, Lieb KR, Hauzenberger C (2007) Diamonds, xenoliths and kimberlites: a window into the earth's mantle. UNESCO IGCP 557. Geochim Cosmochim Acta 71:A95

Spear KE, Dismukes JP (ed) (1994) Synthetic Diamonds: Emerging CVD Science and Technology. Wiley, New York

Speer JA (1977) The orthorhombic carbonate minerals of Virginia. Rocks Minerals 52:267-274

Speer JA (1983) Crystal chemistry and phase relationships of the orthorhombic carbonates. Rev Mineral 11:145-190

Stanley SM, Hardie LA (1998) Secular oscillations in the carbonate mineralogy of reef-building and sediment-producing organisms driven by tectonically forced shifts in seawater chemistry. Palaeogeog Palaeoclimatol Palaeoecol 144:3-19

Strong H (1989) Early diamond making at General Electric. Am J Sci 57:794-802

Suits GG (1960) The Synthesis of Diamonds-A Case History in Modern Science. General Electric, Schenectady, New York

Suits GG (1965) Speaking of Research. Wiley, New York

Sumner DY, Grotzinger JP (1996) Herringbone calcite: petrography and environmental significance. J Sediment Res 66:419-429

Sumner DY, Grotzinger JP (2004) Implications for Neoarchaean ocean chemistry from primary carbonate mineralogy of the Campbellrand-Malmani Platform, South Africa. Sedimentology 51:1273-1299

Sverjensky DA, Lee N (2010) The Great Oxidation Event and mineral diversification. Elements 6:31-36

Swainson IP, Hammond RP (2001) Ikaite, $\mathrm{CaCO}_{3} \cdot 6 \mathrm{H}_{2} \mathrm{O}$ : cold comfort for glendonites as palaeothermometers. Am Mineral 86:1530-1533

Teng HH, Dove PM (1997) Surface site-specific interactions of aspartate with calcite during dissolution: implications for biomineralization. Am Mineral 82:878-887

Teng HH, Dove PM, Orme C, DeYoreo JJ (1998) The thermodynamics of calcite growth: a baseline for understanding biomineral formation. Science 282:724-727

Tian P, Fang Q, Chen K, Peng Z (1983) A study on tongbaite-a new mineral. Acta Mineral Sinica 4:241-245 Tran NT, Min T, Franz AK (2011) Silanediol hydrogen bonding activation of carbonyl compounds. Chemistry Eur J 17:9897-9900, doi: 10.1002/chem.201101492

Treiman AH, Lindstrom DJ, Schwandt CS, Franchi IA, Morgan ML (2002) A "mesosiderite" rock from Northern Siberia, Russia: Not a meteorite. Meteorit Planet Sci 37:B13-B22

Trumbull RB, Yang J-S, Robinson PT, Di Pierro S, Vennemann T, Weidenbeck M (2009) The carbon isotope composition of natural $\mathrm{SiC}$ (moissanite) from Earth's mantle: new discoveries from ophiolites. Lithos 113:612-620

Tuttle OF, Gittins J (ed) (1966) Carbonatites. Wiley Interscience, New York

Ulff-Moller F (1986) A new 10 tons iron boulder from Disko, West Greenland. Meteorit Planet Sci 21:464

Verma AR, Krishna P (1966) Polymorphism and Polytypism in Crystals. Wiley, New York

von Platen B (1962) A multiple piston, high pressure, high temperature apparatus. In: Modern Very High Pressure Techniques. Wentorf RH (ed) Butterworths, Washington, p 118-136

Wächtershäuser G (1988) Before enzymes and templates: theory of surface metabolism. Microbiol Rev 52:452-484

Wächtershäuser G (1990) The case for the chemoautotrophic origin of life in an iron-sulfur world. Origins Life Evol Biosphere 20:173-176

Wächtershäuser G (1993) The cradle chemistry of life: on the origin of natural products in a pyrite-pulled chemoautotrophic origin of life. Pure Appl Chem 65:1343-1348

Walter MJ, Bulanova GP, Armstrong LS, Keshav S, Blundy JD, Gudfinnsson G, Lord OT, Lennie AR, Clark SM, Smith CB, Gobbo L (2008) Primary carbonatite melt from deeply subducted oceanic crust. Nature 454:622-625

Walter MJ, Kohn SC, Araujo D, Bulanova GP, Smith CB, Gaillou E, Wang J, Steele A, Shirey SB (2011) Deep mantle cycling of oceanic crust: evidence from diamonds and their mineral inclusions. Science 334:54 57, doi: 10.1126/science. 1209300

Wang J, Becker U (2009) Structure and carbonate orientation of vaterite $\left(\mathrm{CaCO}_{3}\right)$. Am Mineral 94:380-386

Wang Z, Li G (1991) Barite and witherite in sedimentary rocks of the southeastern part of the Siberian platform. Tr Mineral Muz, Akad Nauk SSSR 22:207-210 
Wasastjerna JA (1924) The crystal structure of dolomite. Soc Sci Fenn Commentat Phys-Math 2:1-14

Weber A (1982) Formation of pyrophosphate on hydroxyapatite with thioesters as condensing agents. BioSystems 15:183-189

Weber A (1995) Prebiotic polymerization: oxidative polymerization of 2,3-dimercapto-1-propanol on the surface of iron(III) hydroxide oxide. Origin Life Evol Biosphere 25:53-60

Wehrmeister U, Jacob DE, Soldati AL (2011) Amorphous, nanocrystalline, and crystalline calcium carbonates in biological materials. J Raman Spectrosc 42:926-935

Wentorf R (ed) (1962) Modern Very High Pressure Research. Butterworths, Washington

White WB (1974) The carbonate minerals. Mineral Soc Monograph 4:227-284

Wilson L, Head JW (2007) An integrated model of kimberlite ascent and eruption. Nature 447:53-57

Wood BJ (1993) Carbon in the core. Earth Planet Sci Lett 117:593-607, doi: 10.1016/ 0012-821X(93)90105-I

Wood BJ, Li J, Shahar A (2013) Carbon in the core: its influence on the properties of core and mantle. Rev Mineral Geochem 75:231-250

Wyckoff RWG, Merwin HE (1924) The crystal structure of dolomite. Am J Sci 8:447-461

$\mathrm{Xu} \mathrm{AW}$, Antonietti M, Colfen H, Fang Y-P (2006) Uniform hexagonal plates of vaterite $\mathrm{CaCO}_{3}$ mesocrystals formed by biomimetic mineralization. Adv Funct Mater 16:903-908

Xu J, Mao H-K (2000) Moissanite: A window for high-pressure experiments. Science 290:783-787, doi: $10.1126 /$ science.290.5492.783

Xu S-T, Wu W-P, Xiao W-S, Yang J-S, Chen J, Ji S-Y, Liu Y-C (2008) Moissanite in serpentinite from the Dabie Mountains in China. Mineral Mag 72:899-908

Yang K-F, Fan H-R, Santosh M, Hu F-F, Wang K-Y (2011) Mesoproterozoic carbonatitic magmatism in the Bayan Obo deposit, Inner Mongolia, north China-Constraints for the mechanism of super accumulation of rare earth elements. Ore Geol Rev 40:122-131

Yergorov NK, Ushchapovskaya ZF, Kashayev AA, Bogdanov GV, Sizykh YI (1988) Zemkorite, $\mathrm{Na}_{2} \mathrm{Ca}\left(\mathrm{CO}_{3}\right)_{2}$, a new carbonate from Yakutian kimberlites. Dokl Akad Nauk SSSR 301:188-193

Yoshioka S, Kitano Y (2011) Transformation of aragonite to calcite through heating. Geochem J 19:245-249

Zaitsev AM (2001) Optical Properties of Diamond. Springer, Berlin

Zhang C, Duan ZH (2009) A model for C-O-H fluid in the Earth's mantle. Geochim Cosmochim Acta 73:20892102, doi: 10.1016/j.gca.2009.01.021

Zhu Q, Oganov AR, Salvado M, Pertierra P, Lyakhov AO (2011) Denser than diamond: ab initio search for superdense carbon allotropes. Phys Rev B 83:193410 